\title{
Proteomic analysis of early salt stress responsive proteins in alfalfa roots and shoots
}

\author{
Junbo Xiong ${ }^{1 \dagger}$, Yan Sun ${ }^{2 \dagger}$, Qingchuan Yang ${ }^{3}$, Hong Tian ${ }^{1}$, Heshan Zhang ${ }^{1}$, Yang Liu ${ }^{1 *}$ and Mingxin Chen ${ }^{1}$
}

\begin{abstract}
Background: Alfalfa (Medicago sativa) is the most extensively cultivated forage legume in the world, and salinity stress is the most problematic environmental factors limiting alfalfa production. To evaluate alfalfa tissue variations in response to salt stress, comparative physiological and proteomic analyses were made of salt responses in the roots and shoots of the alfalfa.

Method: A two-dimensional gel electrophoresis (2-DE)-based proteomic technique was employed to identify the differentially abundant proteins (DAPs) from salt-treated alfalfa roots and shoots of the salt tolerance cultivars Zhongmu No 1 cultivar, which was subjected to a range of salt stress concentrations for 9 days. In parallel, REL, MAD and $\mathrm{H}_{2} \mathrm{O}_{2}$ contents, and the activities of antioxidant enzymes of shoots and roots were determinand.

Result: Twenty-seven spots in the shoots and 36 spots in the roots that exhibited showed significant abundance variations were identified by MALDI-TOF-TOF MS. These DAPs are mainly involved in the biological processes of photosynthesis, stress and defense, carbohydrate and energy metabolism, second metabolism, protein metabolism, transcriptional regulation, cell wall and cytoskeleton metabolism, ion transpor, signal transduction. In parallel, physiological data were correlated well with our proteomic results. It is worth emphasizing that some novel salt-responsive proteins were identified, such as CP12, pathogenesis-related protein 2, harvest-induced protein, isoliquiritigenin 2'-O-methyltransferase. qRT-PCR was used to study the gene expression levels of the four above-mentioned proteins; four patterns are consistent with those of induced protein.

Conclusion: The primary mechanisms underlying the ability of alfalfa seedlings to tolerate salt stress were photosynthesis, detoxifying and antioxidant, secondary metabolism, and ion transport. And it also suggests that the different tissues responded to salt-stress in different ways.
\end{abstract}

Keywords: $\mathrm{NaCl}$ stress, Medicago sativa root and shoot, Two-dimensional electrophoresis, Differentially abundant proteins

\section{Background}

Soil salinity is a world-wide problem, but is most acute in North and Central Asia, South America, Australasia, and the Mediterranean area. The soil solution in saline soils is composed of a range of dissolved salts, such as $\mathrm{NaCl}$, $\mathrm{Na}_{2} \mathrm{SO}_{4}, \mathrm{MgSO}_{4}, \mathrm{CaSO}_{4}, \mathrm{MgCl}_{2}, \mathrm{KCl}$, and $\mathrm{Na}_{2} \mathrm{CO}_{3}$, each of which contribute to salinity stress. However, $\mathrm{NaCl}$ is

\footnotetext{
*Correspondence: liuyang430209@126.com

${ }^{\dagger}$ Equal contributors

${ }^{1}$ Hubei Key Laboratory of Animal Embryo and Molecular Breeding, Institute of Animal and Veterinary Science, Hubei Academy of Agricultural Science, Yaoyuan 1, Hongshan, Wuhan, Hubei 430017, China

Full list of author information is available at the end of the article
}

the most prevalent salt and has been the focus of much of the work on salinity to date $[1,2]$. High $\mathrm{NaCl}$ concentrations affect plant physiology and metabolism at different levels. High concentrations can cause water deficits, ion toxicity, nutrient imbalance, and oxidative stress, leading to molecular damage, growth and yield reductions, and even plant death.

Alfalfa (Medicago sativa L.) is a perennial warm-season forage legume with a high yield and good nutrient contents (crude protein content can reach approximately 16\% to $22 \%$ ), and can be grown on more than 30 Mha worldwide. However, its yield is low in arid and semi-arid 
regions where salinity is the main problem. Alfalfa is moderately tolerant to salinity when the electrical conductivity $(\mathrm{EC})$ is $2.0 \mathrm{dS} / \mathrm{m}(1280 \mathrm{ppm})$ and the soil osmotic potential threshold is 1.5 bars ( 1 bar $=0.987 \mathrm{~atm}$ ) at field capacity. An additional 7\% decrease in alfalfa yields can be expected with each $\mathrm{dS} / \mathrm{m}$ increase in saturation extract salinity [3]. Excessive salinity in the crop root zone creates osmotic stress, which reduces root uptake of water and crop transpiration, leading to reduced forage yields [4].

Understanding the alfalfa tolerance mechanisms to high concentrations of $\mathrm{NaCl}$ in soils may ultimately help to improve yields on saline lands. Previous studies indicated that alfalfa salt tolerance is generally associated with modifications of morphological and physiological traits, such as changes in plant architecture and growth (shoots and roots), variations in leaf cuticle thickness, stomatal regulation, germination, and photosynthesis rate. These changes are linked to diverse cellular modifications, including, changes in membrane and protein stability, increased antioxidant capacity and activation of hormonal signaling pathways, notably those depending on the "stress hormone" abscissic acid [5]. The regulation of these changes at the cellular level are the main responses that cause alterations in gene expression and several attempts have been made to obtain a profile for gene expression in alfalfa under saline conditions $[6,7]$. However, transcript profiles do not always provide a complete story due to limited correlations between the transcript and protein levels, and proteomics has become a critical complement to mRNA data and an improved biological view of plant biology. Currently, several studies have attempted to analyze alterations in protein expression in response to salt, and proteomics studies that focused on 34 plant species have identified 2171 salt-responsive protein identities, representing 561 unique proteins [8]. To date, few studies have investigated the effects of salt stress on alfalfa.

Salt stress induces many different proteomic changes in various plant tissues due to their distinct functions and growth environments. A comparative analysis of different plant tissue responses to salinity stress at the same time would improve understanding of different tissues protein compositions and their differential responses to salinity stress. Furthermore, it would provide further insights into the proteomic mechanisms controlling salt tolerance. A few previous studies examined protein change responses in different tissues to salinity stress, such as the report on soybean (Glycine max L.) leaves, hypocotyls, and roots [9, 10], creeping bentgrass (Agrostis. stolonifera L.) leaves and roots [11], and rice (Oryza sativa L.) leaves and roots [12]. They all suggested that protein responses to salt-stress in different tissues varied and some protein showed tissue specific abundance.

Alfalfa cultivar "Zhongmu No1", one salt tolerance cultivar commonly used in China agriculture, was released by the Chinese Academy of Agricultural Science in 2001. This germplasm represents the four cycle of recurrent mass selection for alfalfa genotypes that germinate at high levels of $\mathrm{NaCl}$. In this study, we analyzed the "Zhongmu No1" cultivar shoot and root responses to different $\mathrm{NaCl}$ concentrations using physiological and biochemical methods, and comparative proteomics. Based on our findings, we produced a possible schematic representation of the mechanism associated with salt tolerance in alfalfa.

\section{Methods}

Plant materials and stress treatments

Alfalfa seeds (Medicago sativa L.cv. Zhongmu No 1) were germinated in the dark for $48 \mathrm{~h}$ at $28{ }^{\circ} \mathrm{C}$, then transplanted into $1 / 2$ Hoagland's nutrient solution and grown on for 7 days. Subsequently, the seedlings were subjected to 0 (control), 100, and $200 \mathrm{mM} \mathrm{NaCl} \mathrm{1/2} \mathrm{Hoagland's} \mathrm{nutrient}$ solution for $9 \mathrm{~d}$. The salt concentration was maintained by a daily input of $50 \mathrm{mM} \mathrm{NaCl}$. The experiments were conducted in a glasshouse chamber that had an average temperature of $27^{\circ} \mathrm{C} / 18{ }^{\circ} \mathrm{C}$ day/night, and a light irradiance of $150 \mu \mathrm{mol} \mathrm{m}{ }^{-2} \mathrm{~s}^{-1}$.

\section{$\mathrm{H}_{2} \mathrm{O}_{2}, \mathrm{MDA}$, and relative electrolyte leakage analyses}

For the $\mathrm{H}_{2} \mathrm{O}_{2}$ content analysis, $1 \mathrm{~g}$ each of root and shoot tissues were ground in liquid $\mathrm{N}_{2}$ and then homogenized in $5 \mathrm{ml}$ cold acetone. The supernatants were used for $\mathrm{H}_{2} \mathrm{O}_{2}$ content assays after centrifugation at $3000 \mathrm{~g}$ and $4{ }^{\circ} \mathrm{C}$ for $10 \mathrm{~min}$. The $\mathrm{H}_{2} \mathrm{O}_{2}$ content was assayed by analyzing the production of titanium-hydroperoxide complex at $410 \mathrm{~nm}$ [13]. MDA was measured using a modified thiobarbituric acid (TBA) method as described previously [14]. Relative electrolyte leakage was determined by modifying a method described previously [15]. A total of $500 \mathrm{mg}$ of tissues were rinsed with $\mathrm{ddH}_{2} \mathrm{O}$, placed in test tubes containing $10 \mathrm{ml}$ of $\mathrm{ddH}_{2} \mathrm{O}$, and incubated at room temperature for $2 \mathrm{~h}$. The electrical conductivity of the solution $\left(C_{1}\right)$ was measured using a conductivity meter (DDS-307A; China). Then the tubes were boiled for $15 \mathrm{~min}$, cooled to room temperature, and the electrical conductivity $\left(\mathrm{C}_{2}\right)$ measured again. The REL was calculated by the formula: $C_{1} / C_{2} \times 100 \%$.

\section{SOD, APX, POD, and CAT activity analyses}

The enzyme extraction and enzyme activity assays were determined by methods modified from those previously described [16]. Root and shoot samples (200 mg each) were ground into fine powder with liquid nitrogen in a pre-chilled mortar and pestle. Further grinding was 
performed in a solution of $50 \mathrm{mM}$ potassium phosphate buffer pH 7.0 containing $1 \mathrm{mM}$ EDTA and 2\% $(w / v)$ polyvinylpolypyrrolidone (PVPP) for the APX and CAT assays, and in a solution of $50 \mathrm{mM}$ potassium phosphate buffer at pH 7.0 containing $0.5 \mathrm{mM}$ EDTA for the SOD and POD assays. The homogenates were centrifuged at $14000 \mathrm{~g}$ for $15 \mathrm{~min}$ at $4{ }^{\circ} \mathrm{C}$. The resulting supernatants were centrifuged again and used immediately for enzyme activity assays or stored at $-30{ }^{\circ} \mathrm{C}$ to be used later. Total SOD (EC 1.15.1.1) activity was determined by monitoring its ability to inhibit the photochemical reduction of nitro blue tetrazolium (NBT). APX activity (EC 1.11.1.11) was determined by following the decrease in ascorbate and measuring the change in absorbance at $290 \mathrm{~nm}$ over $2 \mathrm{~min}$ intervals. The POD (EC 1.11.1.7) and CAT (EC 1.11.1.6) activity were determined by following the decrease in $\mathrm{H}_{2} \mathrm{O}_{2}$, and measuring the change in absorbance at $240 \mathrm{~nm}$ over $2 \mathrm{~min}$ intervals.

\section{Protein extraction and 2-DE}

The total proteins were extracted by a modified TRIzol reagent method, which was recently developed to obtain high-quality proteins from Medicago truncatula tissues for 2-DE [17]. The whole roots and shoots were cut off the seedlings, frozen in liquid nitrogen and ground to a fine powder for protein extraction. Finally, the pellets were dried in a freeze-vacuum dryer for $10 \mathrm{~min}$, resuspended in $1.5 \mathrm{~mL}$ lysis buffer ( $8 \mathrm{M}$ urea, $4 \% \mathrm{v} / \mathrm{v}$ CHAPS, $2 \% \mathrm{w} / v \mathrm{DTT})$, sonicated $(10 \mathrm{~min})$ at $4{ }^{\circ} \mathrm{C}$ and incubated at room temperature for $2 \mathrm{~h}$. The supernatant was collected after centrifugation $\left(40 \mathrm{~min}, 40,000 \mathrm{~g}, 4{ }^{\circ} \mathrm{C}\right.$ ). The protein concentration of the supernatant was determined using a 2-D Quant kit, following the manufacturer's protocol.

Samples containing $120 \mu \mathrm{g}$ total protein in $450 \mu \mathrm{L}$ rehydration buffer (8 M urea, 2\% w/v CHAPS, $1 \% \mathrm{w} / \mathrm{v}$ DTT, $0.5 \%$ v/v IPG buffer $\mathrm{pH} 4-7,0.002 \% \mathrm{w} / \mathrm{v}$ bromophenolblue) were loaded onto a $24 \mathrm{~cm}, \mathrm{pH} 4$ to 7 linear gradient IPGstrip (GE Healthcare, USA). IEF was carried out using an Ettan IPGphorII (GE Healthcare, Uppsala, Sweden). Focusing was performed at $20{ }^{\circ} \mathrm{C}$ as follows: active rehydration at $30 \mathrm{~V}$ for $12 \mathrm{~h}, 150 \mathrm{~V}$ for $1 \mathrm{~h}, 500 \mathrm{~V}$ for $1 \mathrm{~h}, 1000 \mathrm{~V}$ for $1 \mathrm{~h}, 8000 \mathrm{~V}$ for $2 \mathrm{~h}$, and $8000 \mathrm{~V}$ up to $40,000 \mathrm{VH}$. After IEF, the proteins were equilibrated as described. First the IPG strips were incubated in $10 \mathrm{~mL}$ of equilibration buffer $(6 \mathrm{M}$ urea, $30 \% \mathrm{w} / \mathrm{v}$ glycerol, $2 \%$ w/v SDS, $50 \mathrm{mM}$ Tris- $\mathrm{HCl}$, pH 8.8) with $1 \%$ $\mathrm{w} / \mathrm{v}$ DTT for $15 \mathrm{~min}$, and then in the same solution containing $2.5 \% \mathrm{w} / \mathrm{v}$ iodoacetamide instead of DTT for $15 \mathrm{~min}$. Following this, the strips were transferred to $12 \%$ SDS-PAGE gels for second dimension electrophoresis with the Ettan DALTsix gel system (GE Healthcare, Uppsala, Sweden), using SDS electrophoresis buffer (250 mM Tris-base, $1.92 \mathrm{M}$ glycine, 1\% w/v SDS) with a
$0.2 \mathrm{~W} /$ strip for $1 \mathrm{~h}$, and a $15 \mathrm{~W} /$ strip until the dye front reached the bottom of the gel. All 2-DE separations were repeated three times for each tissue extract.

\section{Protein visualization, image analysis}

Upon electrophoresis, Gels gels were stained with silver nitrate according to GE handbook (GE Healthcare, Uppsala, Sweden) with some modifications. Briefly, gels were fixed in $40 \%$ ethanol and 10\% acetic acid for $60 \mathrm{~min}$, and then sensitized with $30 \%$ ethanol, $0.2 \%$ sodium thiosulfate $w / v$, and $6.8 \%$ sodium acetate $\mathrm{w} / \mathrm{v}$ for $30 \mathrm{~min}$. Then gels were rinsed with distilled water three times, $5 \mathrm{~min}$ for each time, then incubated in silver nitrate $(2.5 \mathrm{~g} / \mathrm{L})$ for $20 \mathrm{~min}$. Incubated gels were rinsed with distilled water two times, and developed in a solution of sodium carbonate $(25 \mathrm{~g} / \mathrm{L})$ with formaldehyde $(37 \%, \mathrm{w} / \mathrm{v})$ added $(240 \mathrm{~mL} / \mathrm{L})$ for two times, first for $1 \mathrm{~min}$, then stained for $4 \mathrm{~min}$. Development was stopped with $1.46 \%$ w/v Ethylene Diamine Tetraacetic Acid for $10 \mathrm{~min}$, then gels were rinsed with distilled water three times, $5 \mathrm{~min}$ for each time. Gels were stored in distilled water until they could be processed.Gels images were acquired using a PowerLook 2100XL color scanner (UMAX Technologies, CA, USA) and analyzed with Image master 2D Platinum Software Version 6.0 (GE Healthcare, Uppsala, Sweden).

\section{Protein identification by MALDI-TOF-MS/MS}

Proteins were identified by MALDI-TOF-MS/MS. Selected spots were excised from the gels and destained with a solution containing $20 \% \mathrm{w} / \mathrm{v}$ sodium thiosulphate and $1 \% \mathrm{w} / \mathrm{v}$ potassium ferricyanide for $5 \mathrm{~min}$. The supernatant was removed and the gel spots were washed twice with $25 \mathrm{mM}$ ammonium bicarbonate in $50 \% \mathrm{v} / \mathrm{v}$ acetonitrile for $20 \mathrm{~min}$. The gel spots were then washed in acetonitrile, dried in a Speed-Vac and digested overnight with $20 \mu \mathrm{g} / \mathrm{mL}$ trypsin in $25 \mathrm{mM}$ ammonium bicarbonate at $37{ }^{\circ} \mathrm{C}$. Tryptic peptides were passed through C18 Zip-Tips and mixed with $5 \mathrm{mg} / \mathrm{mL}$ of R-cyano-4-hydroxycinnamic acid, as the matrix, and subject to MALDITOF/TOF analysis (4700 Proteomics Analyzer, Applied Biosystems). Data files obtained from MALDI-TOF/TOF mass spectra were submitted to the Mascot search engine using Daemon 2.1.0 (Matrix Science; http://www.matrixscience.com) on Mascot server version 2.2.1. The data were searched against the NCBInr database and the peptides were constrained to being tryptic with a maximum of one missed cleavage. Carbamidomethylation of cysteine was considered a fixed modification, and oxidation of methionine residues was considered as a variable modification. The identification was based on the combination of a high Mascot score and maximum peptide coverage. 


\section{qRT-PCR analysis}

Total RNA was extracted from salt-treated and control alfalfa roots and shoot by Trizol reagent (TaKaRa), and cDNA was reverse transcribed from $1 \mu \mathrm{g}$ of to total RNA using a First Strand cDNA Synthesis Kit (Invitrogen). Gene-specific primers (GSPs) used for qRT-PCR were designed using primer 5 according to cDNA sequences obtained from the alfalfa (Table 1). The alfalfa Actin gene was used as an endogenous control for normalization. The PCR reaction was carried out in a $20 \mathrm{uL}$ volume containing $10 \mu \mathrm{L} 2 \times$ SYBR Green Master Mix reagent (TaKaRa), $1 \mu \mathrm{L}$ template cDNA and $0.5 \mu \mathrm{L}$ of each GSPs with the following reaction conditions: $95{ }^{\circ} \mathrm{C}$ for $30 \mathrm{~s}$; followed by 40 cycles of $95{ }^{\circ} \mathrm{C}$ for $10 \mathrm{~s} ; 55{ }^{\circ} \mathrm{C}$ for $10 \mathrm{~s}$ and $72{ }^{\circ} \mathrm{C}$ for $15 \mathrm{~s}$. Relative gene expression was calculated using the ddCt alogorithm [18].

\section{Immunoblot analysis}

Protein samples (50 mg/lane) were separated using 12\% one dimensional SDS-PAGE gel electrophoresis, transferred onto nitrocellulose membranes, and incubated at room temperature for $2 \mathrm{~h}$ with rabbit polyclonal antibodies raised against Rubisco activase, Heat shock

Table 1 The primers for qRT-PCR

\begin{tabular}{|c|c|c|c|}
\hline Protein & Genes & Primers & Sequence \\
\hline \multirow[t]{2}{*}{ Actin } & gi|378407816 & $\begin{array}{l}\text { Forward } \\
\text { primer } \\
\left(5^{\prime}-3^{\prime}\right)\end{array}$ & GATACTCTITCACCACAACAGCCG \\
\hline & & $\begin{array}{l}\text { Reverse } \\
\text { primer } \\
\left(5^{\prime}-3^{\prime}\right)\end{array}$ & ACTTCAGGACAACGGAAACGCT \\
\hline \multirow[t]{2}{*}{ CP12 } & gi|3,123,345 & $\begin{array}{l}\text { Forward } \\
\text { primer } \\
\left(5^{\prime}-3^{\prime}\right)\end{array}$ & TGGCAACAATAGGTGGTCT \\
\hline & & $\begin{array}{l}\text { Reverse } \\
\text { primer } \\
\left(5^{\prime}-3^{\prime}\right)\end{array}$ & CTCGTCGGTITCAGGGT \\
\hline \multirow[t]{2}{*}{ HI protein } & gi|283,831,548 & $\begin{array}{l}\text { Forward } \\
\text { primer } \\
\left(5^{\prime}-3^{\prime}\right)\end{array}$ & GCTGATGAAATCGTCCCA \\
\hline & & $\begin{array}{l}\text { Reverse } \\
\text { primer } \\
\left(5^{\prime}-3^{\prime}\right)\end{array}$ & ACCCTGTTCCTCCCACTAAGCTGTA \\
\hline \multirow[t]{2}{*}{$\begin{array}{l}\text { PR } \\
\text { protein } 2\end{array}$} & gi| $44,887,779$ & $\begin{array}{l}\text { Forward } \\
\text { primer } \\
\left(5^{\prime}-3^{\prime}\right)\end{array}$ & CTAAATTACCAGCATCAACGC \\
\hline & & $\begin{array}{l}\text { Reverse } \\
\text { primer } \\
\left(5^{\prime}-3^{\prime}\right)\end{array}$ & CCTCTACTITCATCAGGGACAA \\
\hline \multirow[t]{2}{*}{ IOMT } & gi|22,266,001 & $\begin{array}{l}\text { Forward } \\
\text { primer } \\
\left(5^{\prime}-3^{\prime}\right)\end{array}$ & GCTGATGAAATCGTCCCA \\
\hline & & $\begin{array}{l}\text { Reverse } \\
\text { primer } \\
\left(5^{\prime}-3^{\prime}\right)\end{array}$ & AACCCTGTTCCTCCTACCA \\
\hline
\end{tabular}

protein 70 each (Agrisera, Sweden) at 1:5000 dilution. After washing three times with TBST buffer $(0.01 \mathrm{M}$ TBS, $0.1 \%$ Tween-20, $\mathrm{pH}$ 7.6), the membranes were exposed for $2 \mathrm{~h}$ at room temperature to horseradish peroxidase-conjugated goat anti-rabbit IgG at 1:300 dilution. Positive signals were visualized with 3, 3'diaminobenzidine.

\section{Statistical analysis}

Data from repeated measurements are shown as mean. Comparison of differences among the groups was carried out using Student's test. Significant differences were determined relative to the $P$ value $[P$-values $<0.05(*)$ and $<0.01(*)]$.

\section{Results}

\section{Changes in REL and MAD contents}

REL and MAD are indicators of membrane damage caused by $\mathrm{NaCl}$ stress. Stress-induced REL and MAD changes in the roots and shoots are shown in Fig. 1a, b. These data demonstrated a significant increase in the REL and MAD ( $P$-values $<0.05$ and P-values <0.01) when alfalfa seedlings were treated with $100 \mathrm{mM}$ and $200 \mathrm{mM} \mathrm{NaCl}$. The roots had higher REL and MAD contents than the shoots.

\section{Changes in $\mathrm{H}_{2} \mathrm{O}_{2}$ and antioxidant enzyme activities}

As shown in Fig. 1c, a significant increase in the $\mathrm{H}_{2} \mathrm{O}_{2}$ when alfalfa seedlings were treated with $100 \mathrm{mM}$ and $200 \mathrm{mM} \mathrm{NaCl}(P$-values $<0.05$ and $P$-values $<0.01)$. The shoots had higher $\mathrm{H}_{2} \mathrm{O}_{2}$ contents than the roots. Under normal conditions, the SOD activity was higher in the shoots than in the roots, and it was significant increase $(P$-values $<0.01)$ in roots and shoots when alfalfa seedlings were treated with $100 \mathrm{mM}$ and $200 \mathrm{mM} \mathrm{NaCl}$ (Fig. 1d). The SOD in the roots was 3.78 and 5.29 times higher in 100 and $200 \mathrm{mM} \mathrm{NaCl}$, respectively, than in the control, and was 1.59 and 2.35 times higher than in the shoots. Similarly, the APX activity was significant increase $(P$-values $<0.01)$ in the shoots and roots as the $\mathrm{NaCl}$ concentration increased. Furthermore, the rate of increase in APX activity in the shoots was slower than in the roots (Fig. 1f). Salinity effects on POD activity are shown in Fig. 1e. Under normal conditions, the POD activity in the roots was 5.48 times higher than in the shoots. Salt stress slightly increased the POD activity in the roots and shoots, but it was not significant $(P$-values $>0.05)$. The salt stress treatments up-regulated CAT activity by 2.15 and 2.91 times respectively, in shoot. However, the CAT activity in the roots slightly decreased under salt stress, it was not significant $(P$-values $>0.05)$ (Fig. $1 \mathrm{~g}$ ). 

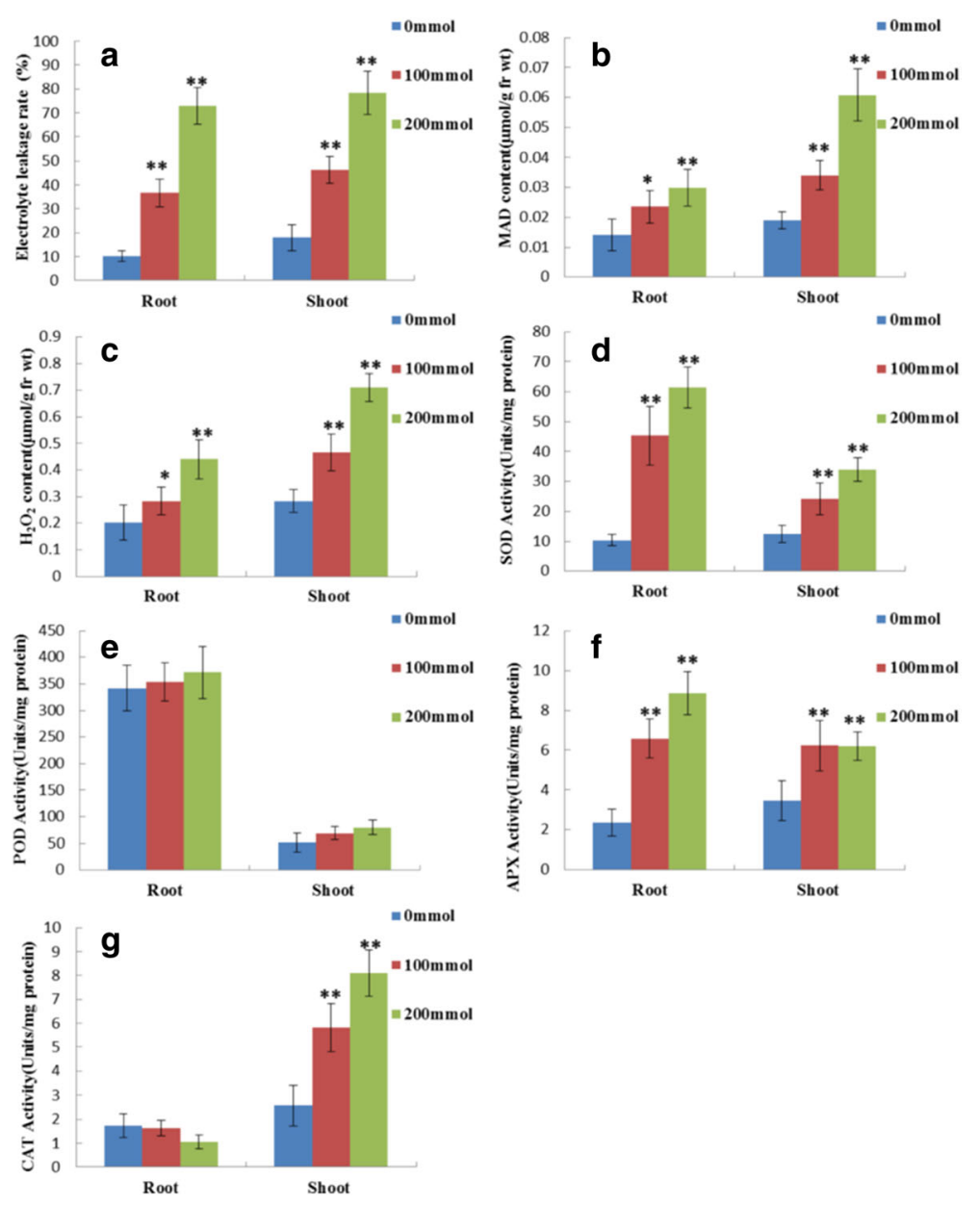

Fig. 1 Physiological responses induced by $\mathrm{NaCl}$ treatment $(0,100,200 \mathrm{Mm})$ for 9 days in Medicago sativa leaves and roots. Effects of salinity on the Relative electrolyte leakage (a), MAD content (b), $\mathrm{H}_{2} \mathrm{O}_{2}$ content (c), SOD activity (d), POD activity (e), APX activity (f), CTA activity (g) were presented. Significant differences were determined relative to each treatment using a student's t-test $\left[P\right.$-values $<0.05\left(^{*}\right)$ and $\left.<0.01\left({ }^{*}\right)\right]$. Bars: SD

\section{Identification and functional classification of DAPs}

More than 850 proteins were detected in each gel by ImageMaster software (Figs. 2 and 3). Comparison of control and salt-treated plants reference gels allowed the identification of differentially spots. Differentially spots were selected based on the following criteria: (i) relative vol\% of the spot with fold change in a comparison $>1.5$ or $<0.67$; (ii) unadjusted significance level $p<0.05$. Then the spots were analyzed by MALDI-TOF-TOF MS, and a total 61 DAPs were identified: 26 spots in the shoots and 35 spots in the roots (Table 2). Differentially expressed proteins were classified based on KEGG (http://www.kegg.jp/kegg/ pathway.html) and previous literature (Fig. 4). In the shoots, the largest two groups were photosynthesis (31\%), and stress and defense (20\%) groups. In the roots, the largest three groups were stress and defense (26\%), metabolism (17\%), and protein translation, processing, and degradation (17\%). It is noteworthy that proteins involved in signaling and ion transport were only found in the roots.

\section{Correlation of 2-DE data with qRT-PCR}

Four mRNAs encoding novel salt-responsive proteins were selected for analysis. We compared the mRNA levels with the 2-DE data, and determined that all of the qRT-PCR results were in good agreement with the2-DE data (Fig. 5).

\section{Immunoblot analysis for RuBisCO activase and heat shock protein 70}

In the current study, the accuracy of 2-DE analysis was further validated by immunoblot analysis. Proteins of alfalfa roots and shoots were separated by onedimensional SDS-PAGE, and immunoblot analysis was performed for Heat shock protein 70 and RuBisCO activase (Fig. 6). 


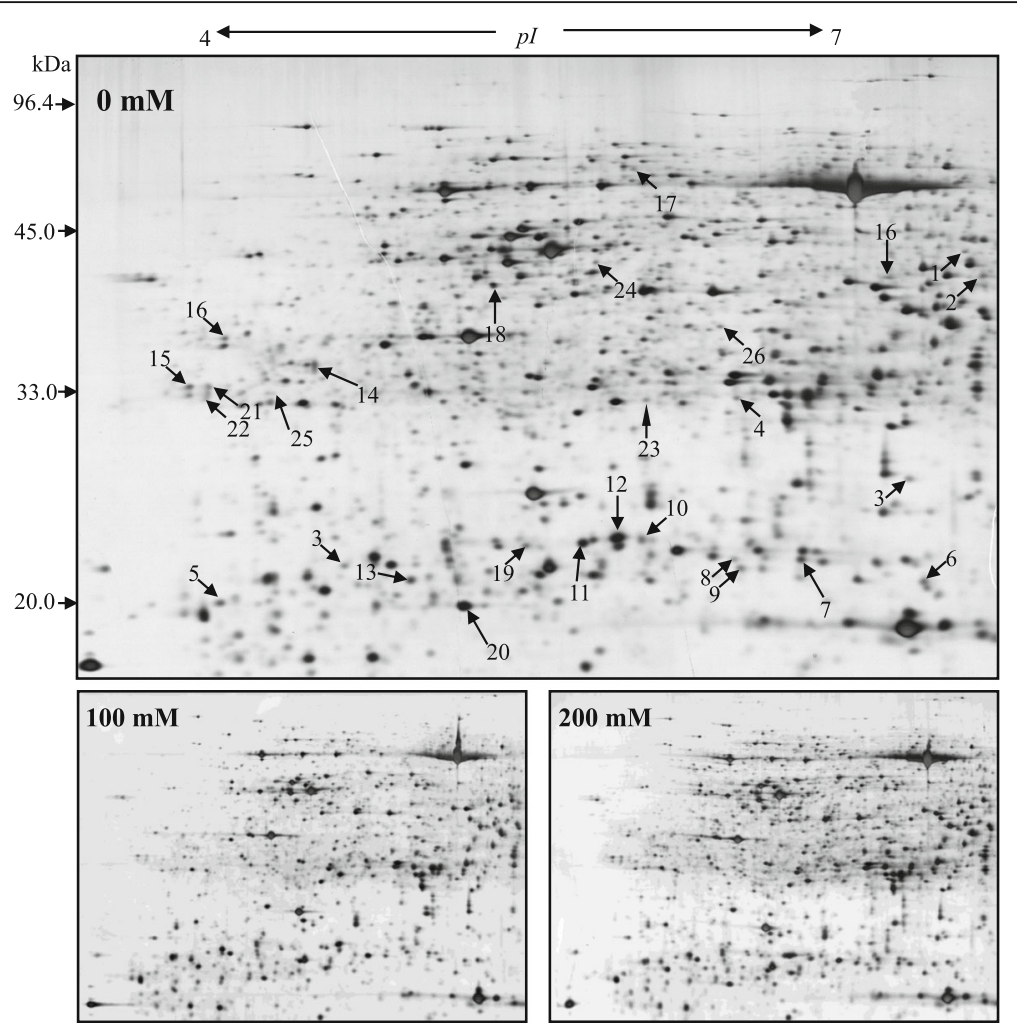

Fig. 2 2-DE analysis of proteins extracted from alfalfa shoot under different salinity. Arrows indicate protein changes induced by NaCl treatment

In agreement with the changes in protein abundance observed by 2-DE, Heat shock protein 70 showed an increased amount in response to $100 \mathrm{mM}$ and $200 \mathrm{mM}$ $\mathrm{NaCl}$ treatment. RuBisCO activase immunoblot analysis revealed an increase amount in response to $100 \mathrm{mM}$ $\mathrm{NaCl}$ treatment, while the $200 \mathrm{mM}$ value is not significantly different from control. This result is different in 2-DE analysis.

\section{Discussion}

Salt stress decreased the growth of both shoots and roots, and this is a well-known physiological change in alfalfa. However, the mechanisms that regulate salt adaptation in alfalfa are complicated and are not well understood. In this study, through a combination of biochemical and proteomic approaches, we were able to undertake a comprehensive analysis of salt stress responses and defense in alfalfa shoots and roots for the first time.

\section{Proteins involved in photosynthesis}

Photosynthesis is one of the most important processes to be affected by salinity. The effects of salt stresses on photosynthesis are either direct, such as diffusion limitations through the stomata and the mesophyll, and alterations in photosynthetic metabolism, or secondary, such as the oxidative stress arising from the superimposition of multiple stresses [19]. Therefore, it was not surprising to observe that the abundance of eight proteins involved in photosynthesis were altered under $\mathrm{NaCl}$ treatment. Among these proteins, three thylakoid membrane proteins: cytochrome b6-f complex iron-sulfur (Cyt b6/f, spot 12), chlorophyll a/b binding protein $(\mathrm{CAB}$, spot 16$)$, and chloroplast oxygen-evolving enhancer protein 1 (OEE1, spot 26) were down-regulated by salt-stress. These proteins are involved in the light reactions, including electron transfer, light-harvesting, and lightinduced oxidation of water. As previously pointed out, salt stress can limit $\mathrm{CO}_{2}$ fixation, and the reducing power production rate is greater than the rate of its use by the Calvin cycle. The excess reducing power will induce the production of reactive oxygen species, thus the protection mechanisms against excess reducing power are an important strategy for combating salt stress [19]. In our study, the downregulated proteins involved in the light reactions will help alfalfa to reduce reducing power production. However, in some salt-tolerant plants, such as Thellungiella halophila, Agrostis stolonifera, and Kandelia candel, salt stress induced the up-regulation of light reaction proteins [20-22]. 


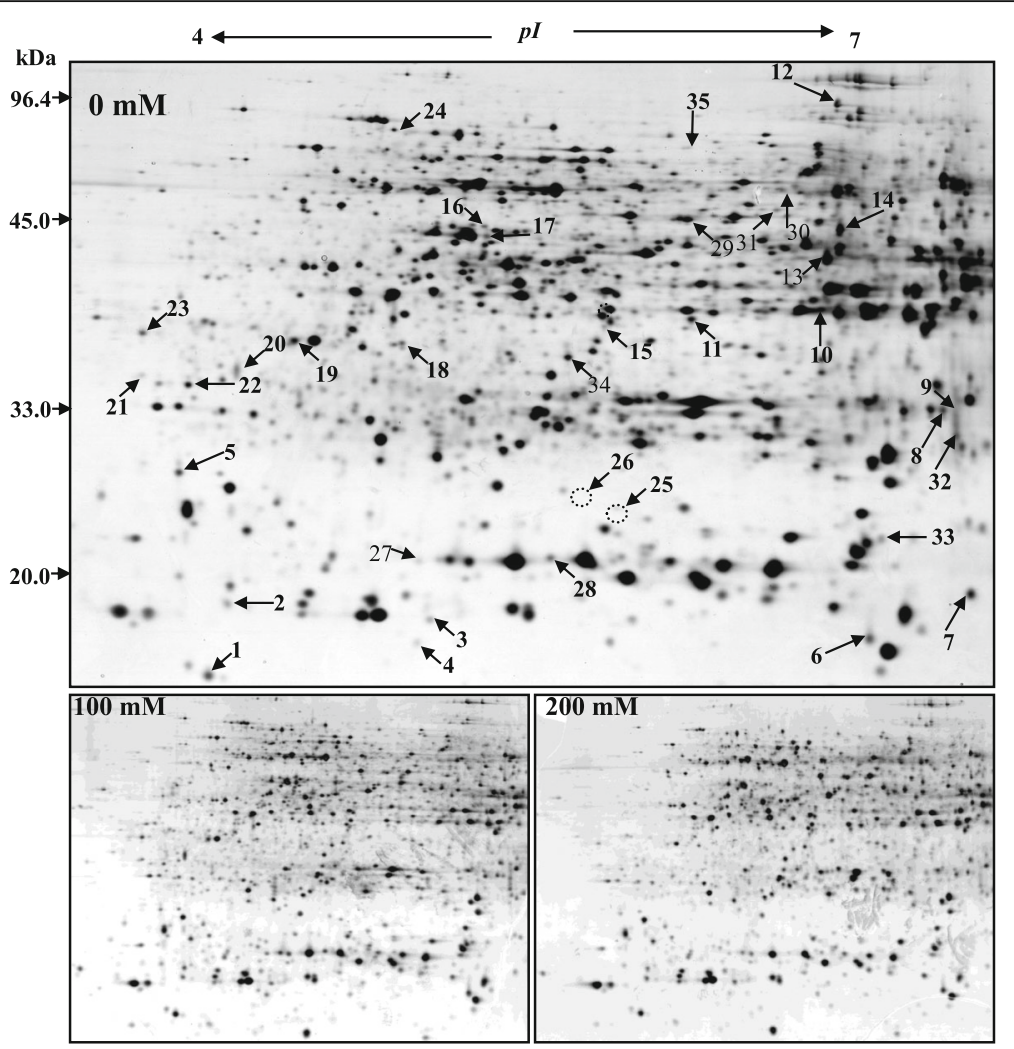

Fig. 3 2-DE analysis of proteins extracted from alfalfa roots under different salinity. Arrows indicate protein changes induced by $\mathrm{NaCl}$ treatment

Three spots (spots 2, 3, and 4) were identified as RuBisCO subunits. RuBisCO, created either through the carboxylation or oxygenation of ribulose-1,5-bisphosphate with carbon dioxide or oxygen, respectively, is composed of eight large subunits and eight small subunits. RuBisCOs are the most common enzymes in plants and salt stress induced altered abundance of RuBisCO subunits have been found in almost all green plant leaves. Previous studies showed that oxidative stress may lead to small-subunit degradation, which subsequently leads to translational arrest of the large subunit. Alternatively, oxidative stress could initially arrest large subunit translation, resulting in a rapid degradation of the unassembled small subunits [23]. It is noteworthy that a RuBisCO activase protein (spot 8) was up-regulated as the salt concentration rose. The principal role of RuBisCO activase is to release inhibitory sugar phosphates, such as ribulose-1,5-biphosphate, from the active RuBisCO sites so that $\mathrm{CO}_{2}$ can activate the enzyme controlling carbamylation. Therefore it ultimately determines the proportion of available RuBisCO active sites that are catalytically competent [24, 25]. Salt-stress directed reduction in stomatal conductance and subsequent low $\mathrm{CO}_{2}$ levels, together with the upregulation of activase activity, may be required in order to induce salt stress tolerance. Previous studies have shown that salt stress induced the up-regulation of RuBisCO activase in rice leaf lamina, barley, and wild halophytic rice [26-28].

A CP12 (spot 6) protein was down- regulated after the $200 \mathrm{mM} \mathrm{NaCl}$ treatment in the shoots. CP12 is a small nuclear encoded chloroplast protein, which, in chloroplasts, is oligomerized with phosphoribulokinase (PRK) and $\mathrm{NADP}^{+}$-GAPDH in the presence of $\mathrm{NAD}(\mathrm{H})$ to generate a PRK/CP12/GAPDH complex. However, the complex dissociates in the presence of $\operatorname{NADP}(\mathrm{H})$. In Synechococcus, the oligomerization of CP12 with PRK and GAPDH regulates the activities of both enzymes and thus the carbon flow from the Calvin cycle to the oxidative pentose phosphate cycle [29]. In this manner, the down-regulated of $\mathrm{CP} 12$ seem to induce by the depression of photosynthesis.

Stress responsive proteins form the largest protein group Salt stress causes the production of excessive reactive oxygen species (ROS), which oxidize cellular components and irreversibly damage plant cells. In the present study, a total of 8 identified proteins were found to obviously relate to anti-oxidative reactions in alfalfa seedling roots and shoots in response to salt stress. All these proteins were up-regulated under $100 \mathrm{mM}$ and /or $200 \mathrm{mM}$ $\mathrm{NaCl}$ stress in alfalfa shoots and/or roots. The 8 proteins 


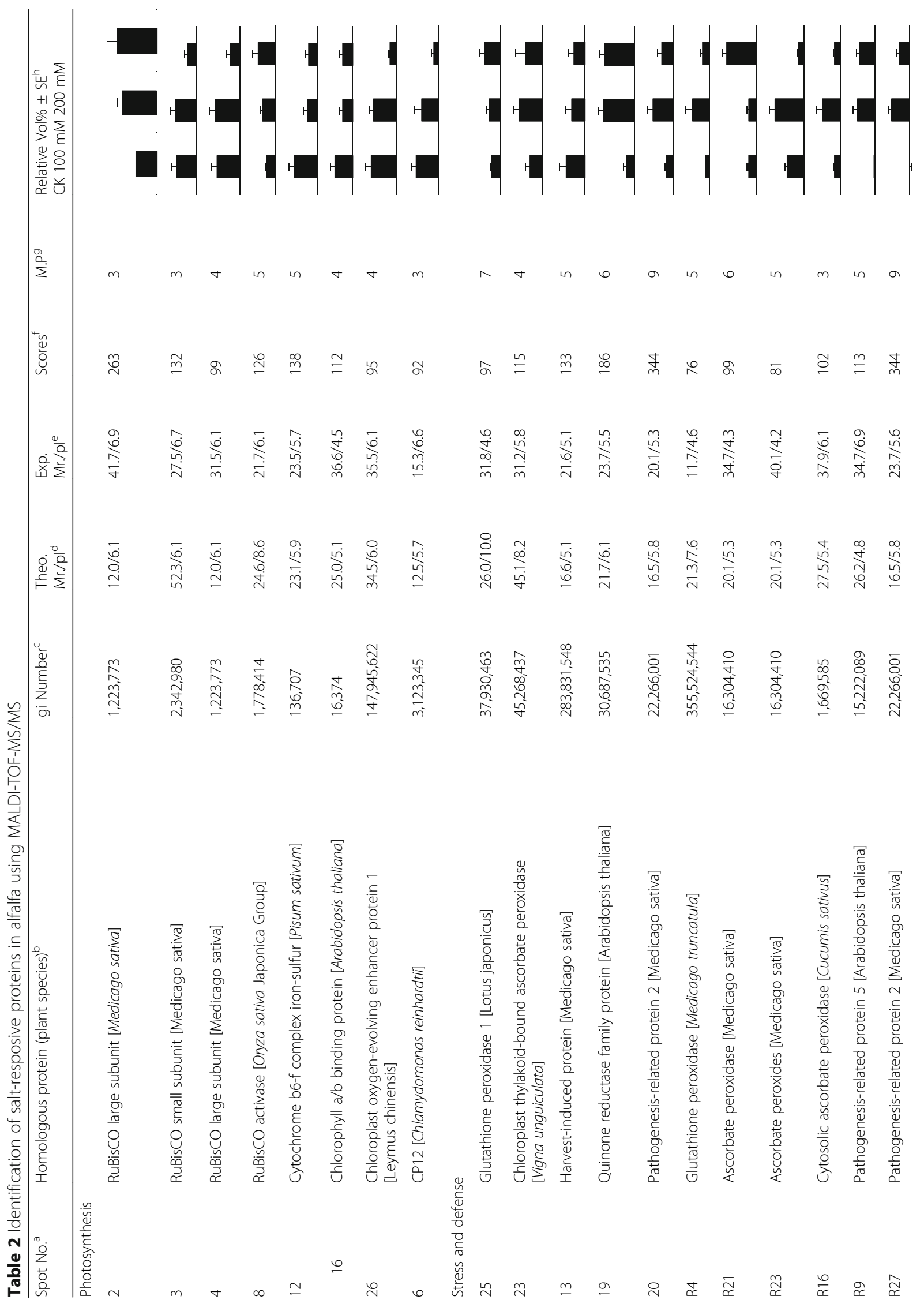




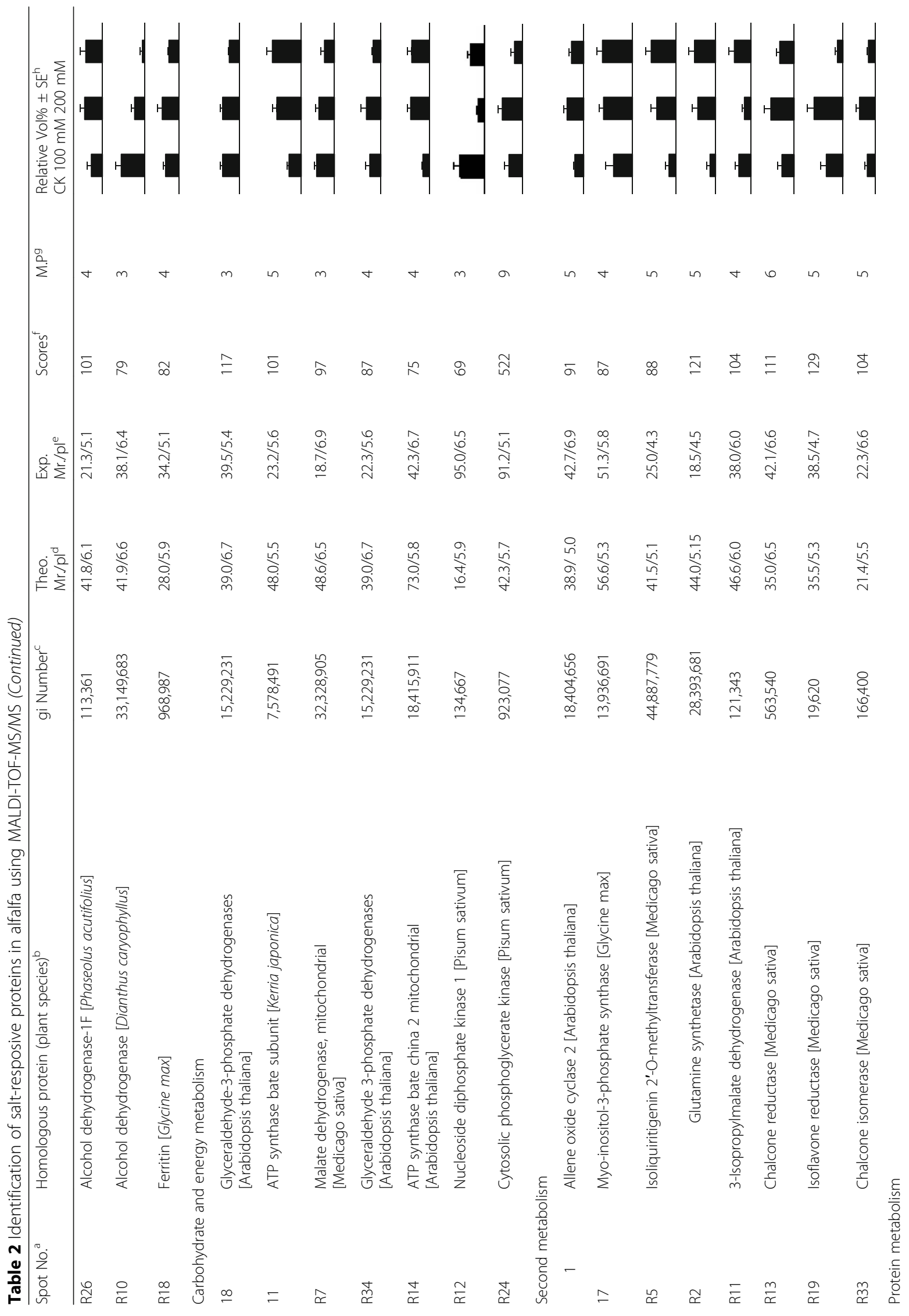




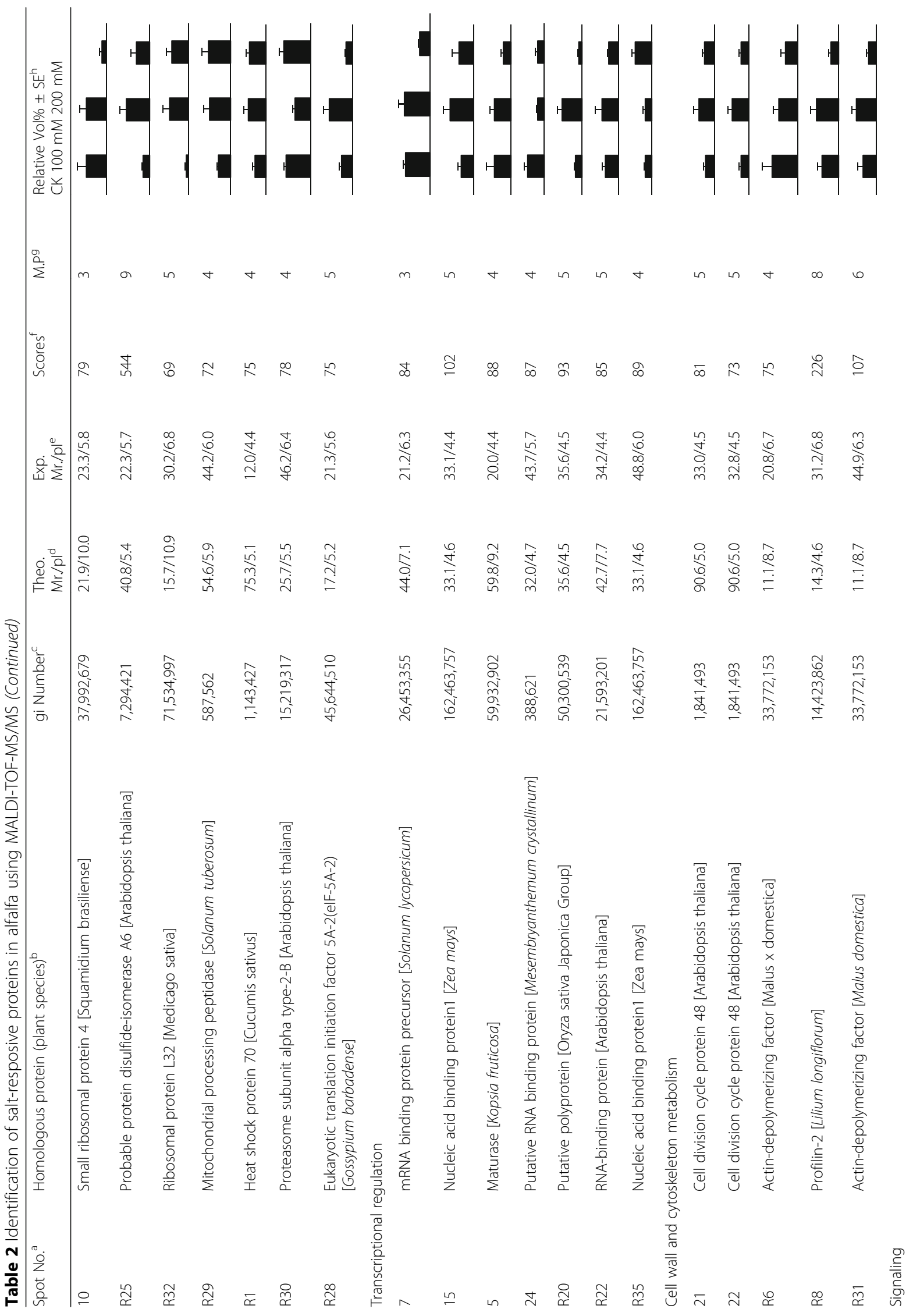




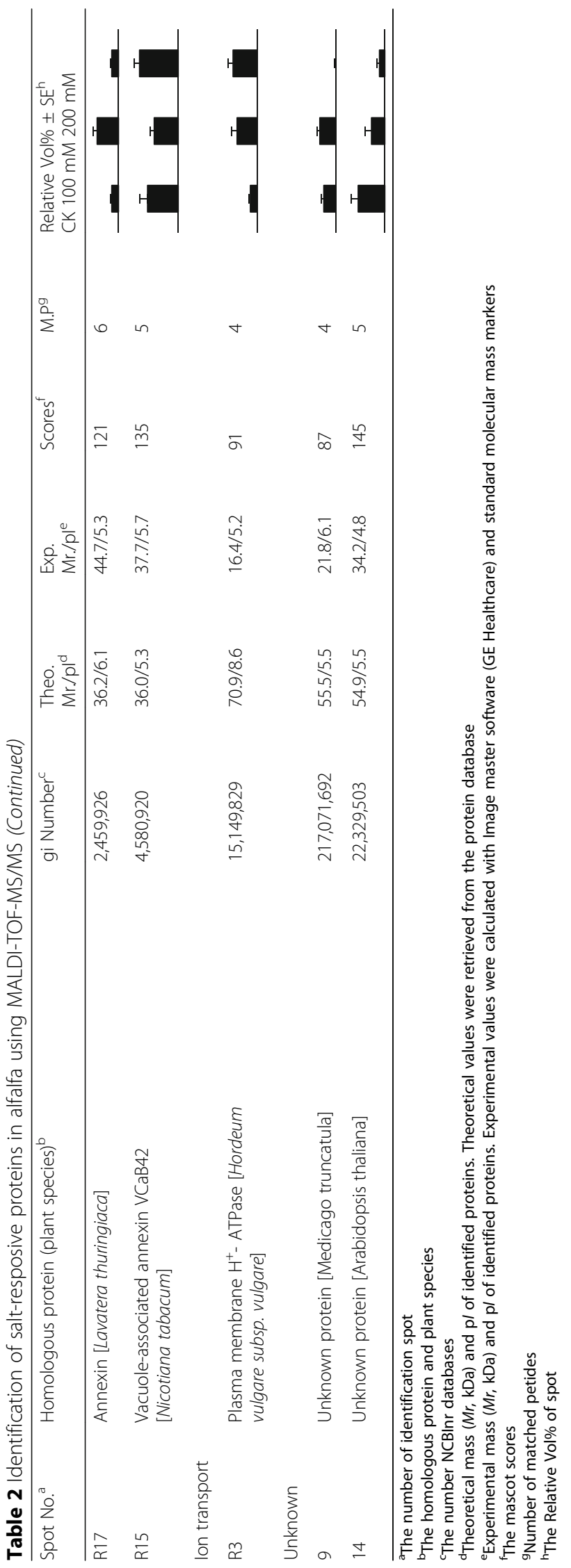




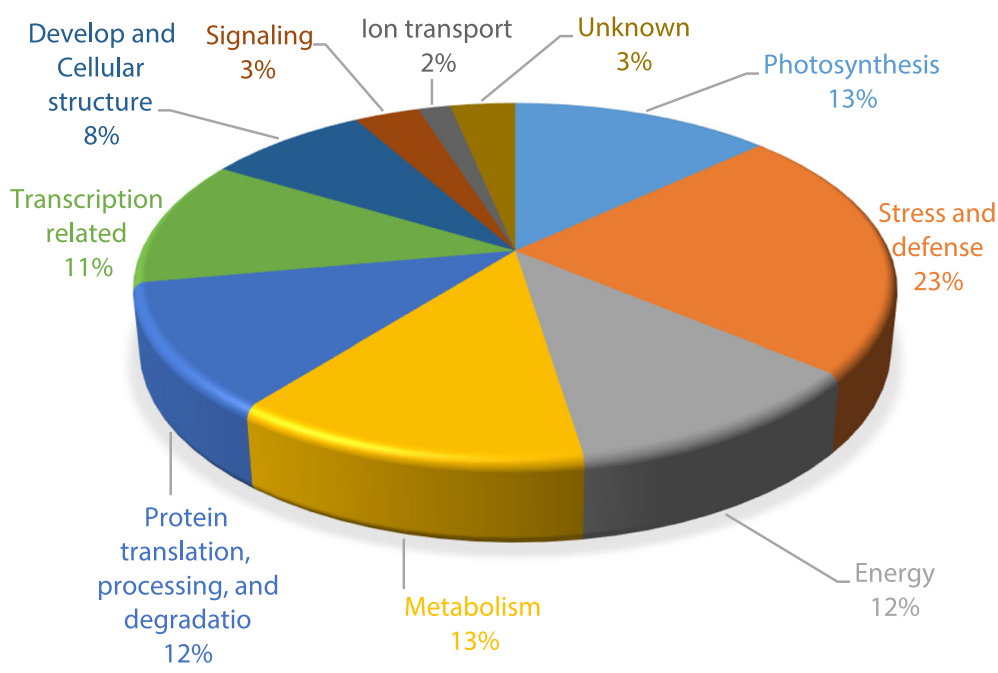

Fig. 4 Functional classification of differentially abundant proteins identified in the seedling shoot and root of alfalfa under salt stress. The pie chart shows the distribution of the salt-responsive proteins into their functional classes in percentage

included 4 ascorbate peroxidases (spots 23, R16, R21, R23), 2 glutathione peroxidase (spots 25, R4), 1 ferritin protein (spot R18), and 1 quinone reductase family protein (spot 19). These proteins are major ROS-scavenging proteins, providing plant cells with highly efficient machinery for detoxifying $\mathrm{H}_{2} \mathrm{O}_{2}$ and the other ROS. However, all of these identified proteins had more distribution in root than in shoots. Our proteomics results might indicate that alfalfa seedling would increase ROSscavenging proteins in response to salt stress and root may have stronger ROS-scavenging capability than shoot. REL and MAD are important indicators of membrane damage caused by ROS stress. In this study, the $\mathrm{H}_{2} \mathrm{O}_{2}$, REL and MAD contents were similar for all the $\mathrm{NaCl}$ concentrations, and all three were higher in the shoots than in the roots. A possible reason is that roots
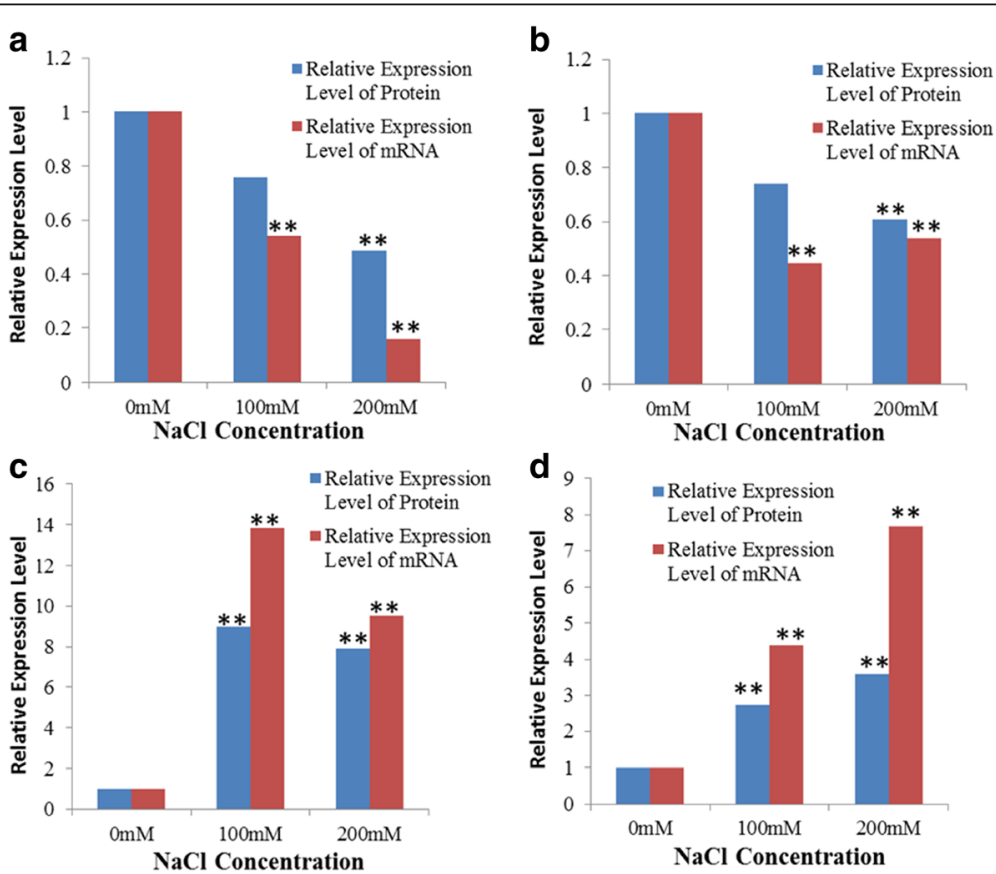

Fig. 5 Transcript abundances of mRNAs encoding four novel salt-responsive proteins were analyzed following salt stress treatment. The mRNA levels were compared with the 2-DE data. Significant differences were determined relative to each treatment using a student's t-test $\left[\right.$-values $<0.05\left(^{*}\right)$ and $\left.<0.01\left(^{* *}\right)\right]$. a CP12 (gi|3,123,345). b Harvest-induced protein $(\mathrm{HI}, \mathrm{gi} \mid 283,831,548)$. c Pathogenesis-related protein 2 (PR2,gi|44,887,779). d Isoliquiritigenin 2'-O-methyltransferase(IOMT, gi|22,266,001) 


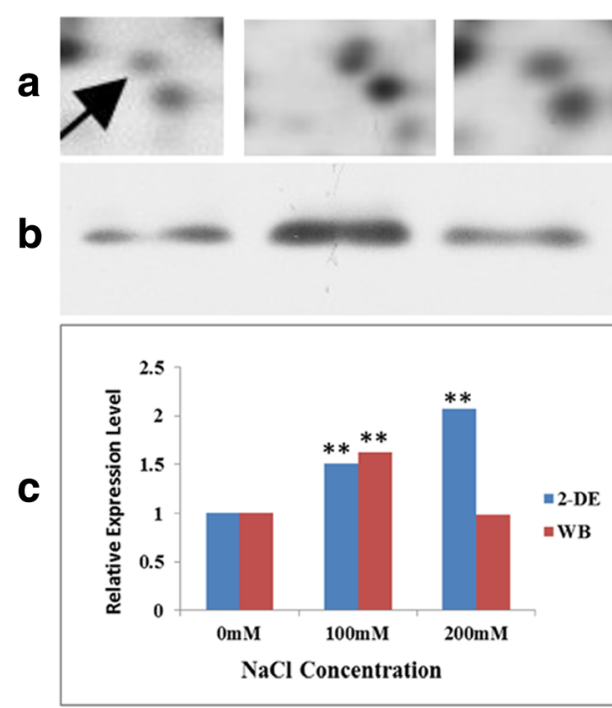

RuBisCO activase
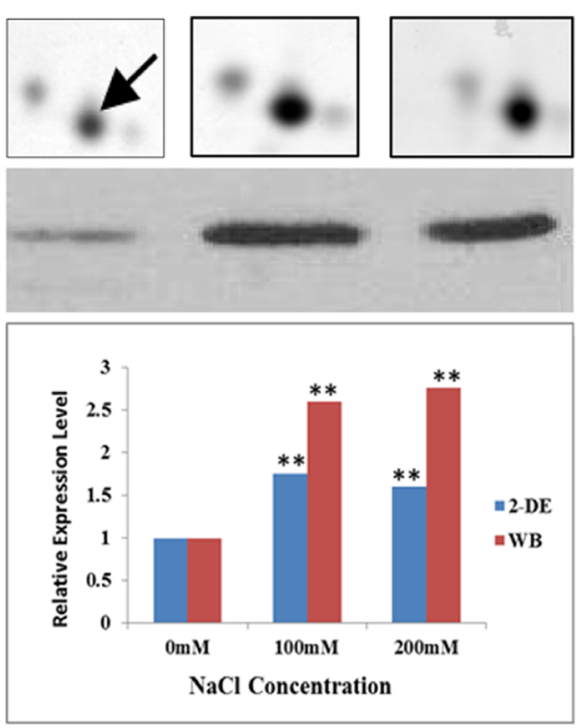

Heat shock protein 70

Fig. 6 Western blot and 2-DE analysis of RuBisCO activase and HSP70 abundant patterns and the relative adundance level in alfalfa. a Antibodies against RuBisCO activase and HSP70 were used to detect the change of protein levels in alfalfa in response to salt stress treatment of the plants; $\mathbf{b}$ Image of RuBisCO activase and HSP70 spots on 2-DE gels; c Gray analysis of the relative adundance of RuBisCO activase and HSP70 (spots 8 and R1) were compared with the 2-DE data. Significant differences were determined relative to each treatment using a student's t-test $\left[P\right.$-values $<0.05\left(^{(*)}\right.$ and $\left.<0.01\left(^{* *}\right)\right]$

may have a better antioxidative defense system than the shoots. To validate the hypothesis, four enzymes involved in ROS scavenging were selected for activity analysis. It is important to note that the roots had higher SOD, APX and POD activities, and the shoots had higher CAT activities. CAT is known to have a lower affinity to $\mathrm{H}_{2} \mathrm{O}_{2}$ than POD ( $\mathrm{mM}$ and $\mu \mathrm{M}$ range, respectively), and lower CAT activities were correlated to salt tolerance simply because large increases in CAT activity was not essential as long as POD and APX imposed tight controls on the $\mathrm{H}_{2} \mathrm{O}_{2}$ concentration [30]. This suggests that different mechanisms control the response to ROS.

In addition to the redox related proteins, plants have developed cross-tolerance mechanisms to be able to cope with different stresses. Some biotic stress-related proteins were induced under salt stress conditions, such as Pathogenesis-related protein 5(PR5, spot R9), Pathogenesisrelated protein 2(PR2, spots 20, R27). PR2 is encoded by $\beta$ 1,3-glucanase gene, and plant $\beta$-1, 3-glucanases are induced not only by pathogen infection, but also by other factors. Stress factors like wounding, drought, exposure to heavy metals, air pollutant ozone, and ultraviolet radiation can stimulate synthesis of $\beta-1,3$-glucanases in some plants [31]. However, there was few reported about it induced by salt stress. Previously, PR5 was gradually increased in abundance with increasing concentrations of $\mathrm{NaCl}$ in Arabidopsis, but the change was the opposite in Thellungiella [21]. PR proteins have been found to be induced in several plant species when they are infected by viruses, viroids, fungi or bacteria. In our study, the PR protein was induced by salt stress, which suggested that it had a special role in plant adaptation to salt stress, but whether it can be used as a potential salt stress marker in alfalfa needs further research. Moreover, some abiotic stress-related proteins, such as alcohol dehydrogenase (ADH, spots R10, R26) and harvestinduced protein (HI, spot 13) also respond to salt stress. $\mathrm{ADH}$ enzymes were traditionally of interest because of their activity during oxygen deprivation [32]. However, more recently, $\mathrm{ADH}$ gene expression and $\mathrm{ADH}$ activity have been shown to be affected by a number of other stresses [33, 34]. ADH1 has been found to be up-regulated in Porteresia coarctata under high salinity and this study also suggested that $\mathrm{ADH} 1$ was up-regulated when alfalfa was subjected to salt stress. HI proteins are involved in defense responses and the response to biotic stimulus, but their molecular details are poorly understood.

\section{The main energy metabolism associated proteins were down regulated}

Salt-stress led to a reduction in photosynthesis, and thus to decreased carbohydrate synthesis. It also inhibited energy production. Energy production declined as the $\mathrm{NaCl}$ concentration increased. There were three proteins involved in glycolysis and the citrate cycle decreased after $\mathrm{NaCl}$ treatment.

The abundance of two glyceraldehyde-3-phosphate dehydrogenases (GAPDH, spots 18, R34) were altered in 
both the roots and shoots. Previous studies have shown that salt stress induces the up-regulation of GAPDH in rice leaves, OSRK1 transgenic rice roots, sugarcane, and in Arabidopsis thaliana roots $[15,35,36]$. The upregulation of GAPDH may increase soluble sugars accumulation and provide more energy for plants under stress. It is therefore an indicator of stress tolerance. In this study, GAPDH was down-regulated in the shoots under $200 \mathrm{mM} \mathrm{NaCl}$ treatment, but was up-regulated in the roots under the $100 \mathrm{mM} \mathrm{NaCl}$ treatment. In addition, the abundance of a cytosolic phosphoglycerate kinase (cPGK, spot R24) was also altered in the roots. PGK is the seventh enzyme in the cycle that catalyzes the reaction of 1,3biphosphoglycerate and ADP to produce 3phosphoglycerate and ATP. GAPDH and PGK are crucial enzymes in the glycolysis cycle and showed the same abundance trends as GAPDH in the roots, which presumably reflects altered carbon flux patterns in response to the increased need for osmotic adjustment in the roots. Furthermore, a malate dehydrogenase mitochondrial (miMD, spot R7) was down-regulated under salt-stress in the roots. Overexpression of malate dehydrogenase in transgenic alfalfa enhances organic acid synthesis and confers tolerance to aluminum [37]. Malate dehydrogenase (cytoplasmic) was up-regulated under $\mathrm{NaCl}$ stress in cucumber roots and young rice panicles $[38,39]$, whereas in our study, malate dehydrogenase was down-regulated under salt stress. A possible reason is that the MD cellular localization was different in each species.

Up abundance of the ATP $\beta$ synthase subunit was observed in both the roots and shoots under salt stress (spots 11, R14). ATP synthase includes two regions: an F0 region and F1 region consisting of $\alpha, \beta$, $\gamma, \delta$, and $\varepsilon$ subunits. ATP synthase $\beta$ subunit induction by salt stress has been reported in plants [12, 40, 41] and those studies show a positive correlation between the abundance of ATP synthase and a plant's ability to resist salt stress. A nucleoside diphosphate kinase 1 (NDPK1, spot R12) was down-regulated under salt stress NDPKs are housekeeping enzymes, and their main function is to transfer a $\gamma$-phosphate from ATP to a cognate nucleoside diphosphate, thereby balancing the nucleoside pool. NDPK has been reported in response to drought [42, 43], cold [44], high temperature [45], and salt stresses $[22,38]$. A recent study showed that NDPK 2 was involved in salt stress and $\mathrm{H}_{2} \mathrm{O}_{2}$ signaling in Arabidopsis thaliana [46].

\section{Salt-stress induced some secondary metabolism proteins}

Secondary metabolism is a unique plant characteristic, is critical growth and development, and also allows plants to adapt to changing environments. Plant cells produce a vast number of secondary products, and some compounds are restricted to single species.
Flavonoids are ubiquitous plant secondary products that are best known as the characteristic red, blue, and purple anthocyanin pigments seen in plant tissues. In our study, isoflavone reductase (IFR, spot R19), isoliquiritigenin 2'-O-methyltransferase (IOMT, spot R5), chalcone reductase (CHR, spot R13), and chalcone isomerase (CHI, spot R33) showed up-regulated by salt stress in the seedling roots under $100 \mathrm{mM}$. Previously, it has been reported that flavonoids act as attractants to pollinators and symbionts, as sunscreens to protect against UV irradiation, as allelochemicals, as antimicrobial and antiherbivory factors, and are involved in resistance to aluminum toxicity $[47,48]$. It is noteworthy that the key enzyme involved in flavonoid metabolite production showed an up-regulation under moderate $\mathrm{NaCl}$ treatment, which suggested that flavonoids also respond to the salt stress.

It well known that plants accumulate compatible osmolytes and osmoprotectants that help them to resist salt and drought stress. A L-myo-inositol 1-phosphate synthase (MIPS, spot 17) was up-regulated by salt stress in the shoots. The structure of this protein has been wellstudied and was found to be inherently salt-tolerant [49]. Previous studies have suggested that salt stress induced the accumulation of MIPS in Mesembryanthemum crystallinum and that it was slightly upregulated in $P$. coarctata $[27,50]$.

It has been reported that an number of amino acids increase in alfalfa following $\mathrm{NaCl}$ treatment [51]. Glutamine synthetase 58 (GS58, spot R2) was up-regulated by both the salt stress treatments. GS catalyzes the ATPdependent condensation of ammonium with glutamate to yield glutamine, which then provides nitrogen groups for the biosynthesis of all nitrogenous compounds in the plant [52]. Because glutamate is a precursor of proline, GS activation may contribute to proline synthesis under salt stress [53]. Previous reports indicated that GS was upregulated under salt stress in rice and Arabidopsis roots $[15,54,55]$. A 3-isopropylmalate dehydrogenase (IMD, spot R11), which is involved in Leu biosynthesis, and cobalamine-independent methionine synthase, decreased in abundance following $100 \mathrm{mM} \mathrm{NaCl}$ treatment, but were up-regulated following $200 \mathrm{mM} \mathrm{NaCl}$ treatment. In Arabidopsis roots, IMD decreased in abundance following $\mathrm{NaCl}$ treatment [15], and the abundances of two IMDs were also influenced by $\mathrm{NaCl}$ in Oryza sativa roots [12].

This study also revealed that many protein related hormones were synthesized in response to salt treatment in alfalfa. An allene oxide cyclase 2(AOC2, spot 1) protein was up-regulated under salt stress. AOC catalyzes the stereospecific cyclization of an unstable allene oxide to $9(\mathrm{~S}), 13(\mathrm{~S})-12$-oxo-10,15(Z)-phytodienoic acid, the precursor of jasmonic acid (JA) [56]. $\mathrm{JA}$ is involved in a wide range of stress, defense, and 
developmental processes [57].Transgenic plants expressing a tomato allene oxide cyclase (AOC) also displayed enhanced salt tolerance [58]. Up-regulation of AOC2 protein has been previously reported in Arabidopsis under salt-stress [15, 21].Our results provide additional evidence that AOC improves plants survival under salt stress.

\section{Salt stress induced protein metabolism}

Several proteins, involved in protein translation, processing and degradation, were identified. In our study, ribosomal proteins S4(RP S4, spot 10) was downregulated under $200 \mathrm{mM} \mathrm{NaCl}$ in the shoots, while, RP L32 (spot R32) was up-regulated under salt stress in root. Ribosomes are essential ribonucleoprotein complexes that are engaged in translation and thus play an important role in metabolism, cell division, and growth. The levels of some of the ribosomal proteins decreased while some specific ribosomal components increased under salt stress were also reported on Arabidopsis [59] and Gossypium hirsutum [60]. Moreover, our data showed a eukaryotic translation initiation factor, $5 \mathrm{~A}-2$ (eIF $5 \mathrm{~A}-2$, spot R28), was up-regulated under $100 \mathrm{mM} \mathrm{NaCl}$, but downregulated under $200 \mathrm{mM} \mathrm{NaCl}$. EIF 5A-2 is part of the start site selection for the eIF2-GTP-tRNAi ternary complex within the ribosomal-bound preinitiation complex, and also stabilizes the binding of GDP to eIF2. Alter abundance of eIF5A protein has also been reported in rice leaf lamina and SnRK2 transgenic rice under salt stress $[26,55]$. Other eukaryotic translation initiation factor, such as eIF3I, were also found downregualted under salt-stress in Arabidopsis roots and Gossypium hirsutum roots [15, 60]. All of these studies suggest that complicated regulation mechanisms may govern protein synthesis in order to help plants cope with salt stress.

Several proteins that promote the proper folding of proteins and/or prevent the aggregation of nascent or damaged proteins were detected. A protein, disulfideisomerase A6 (PDI A6, spot R25), was up-regulated under $100 \mathrm{mM} \mathrm{NaCl}$ treatment but down-regulated under $200 \mathrm{mM} \mathrm{NaCl}$ treatment. A major function of PDI is as a chaperone, where it helps wrongly folded proteins to reach a correctly folded state without the aid of enzymatic disulfide shuffling [61]. Moreover, increased abundance of PDI protein has also been reported in rice roots [62] and Gossypium hirsutum roots [60]. A heat shock protein, 70 (HSP70, spot R1), was up-regulated under $\mathrm{NaCl}$ stress. HSPs are grouped into five families: HSP100s, HSP90s, HSP70s, HSP60s, and sHSPs (small HSPs), and may prevent misfolding and promote the refolding and proper assembly of the unfolded polypeptides generated. Experiments in which chrysanthemum HSP70 gene was overexpressed in Arabidopsis thaliana showed that an increase in HSP70 abundance led to a remarkable tolerance to heat, drought and salt [63]. In our study, HSP70 was up-regulated by exposure to high salinity, which suggested that the proteins play a crucial role in aiding the folding and assembly of proteins under salt stress in alfalfa seedlings. These results are similar to the results reported for Kandelia candel, Saccharum spp., Brachypodium distachyon, and Oryza sativa under salt stress [12, 20, 40,64]. A proteasome subunit alpha type-2-B (spot R30), which is involved in protein degradation, accumulated under salt stress in the roots. The proteasome is a very large protein complex (26S) containing a $20 \mathrm{~S}$ core particle, and is a multicatalytic protease that degrades proteins using an ATP-dependent mechanism by which cells regulate the concentration of particular proteins and degrade misfolded proteins [65]. The degradation process yields peptides that are about seven to eight amino acids long, which can then be further degraded into shorter amino acid sequences that can be used to synthesize new proteins [66]. In Brachypodium distachyon, a proteasome subunit was down-regulated in the salt-treated group but up-regulated in the recovery group, which suggested that it was mainly involved in abnormal condition recovery rather than in the defense against salt stress [64]. In our study, the refold-associated proteins were up-regulated, which suggested that alfalfa handles misfolded proteins mainly through refolding. One possible reason is that energy production is depressed under salt stress and degradation is an energy-consuming process.

\section{Transcriptional and translational control is a part alfalfa's response to salt stress}

Under salt stress, many response and defense-related genes are stimulated by upstream transcription regulatory factors, but the genes involved in normal plant growth and development are inhibited [64]. Gene expression regulation is achieved at several levels, i.e. transcriptional, post-transcriptional, translational, and post-translational levels. For example, a maturase protein (spot 5) involved in post-transcription was downregulated under $200 \mathrm{mM} \mathrm{NaCl}$ in the shoots. In vivo, most plant group II introns do not self-splice, but require the assistance of proteinaceous splicing factors, known as maturases [67, 68]. Maturase genes can be found in fungal and plant mitochondria, as well as in plant chloroplasts, and the down-regulation of this protein may be related to the translation of related genes. Two nucleic acid binding proteins (NABP1, spots 15, R35) showed altered abundance in both the shoots and roots under salt stress. NABP is a small and highly conserved protein with nucleic acid chaperone activity that binds single-stranded nucleic acids [69]. One group of 
NABPs is the cold shock domain (CSD) containing proteins, and these CSDPs are involved in various cellular processes, including adaptation to low temperatures, cellular growth, nutrient stress, and the stationary phase [70, 71]. RNA-binding proteins (RBPs) have crucial roles in various cellular processes, such as cellular function, transport, and localization. They also play a major role in post- transcriptional control of RNAs, such as splicing, polyadenylation, mRNA stabilization, mRNA localization, and translation. In this study, three RNA binding proteins (spots 7, 24, R22) were identified.

\section{Salt stress depressed the abundance of proteins involved in cellular processes}

Salt stress decreased the growth of alfalfa, and several proteins associated with the dynamic changes of cellular processes were found in the current study. The actin cytoskeleton plays a critical role in plant development by regulating a number of fundamental cellular processes, including cell division, cell expansion, organelle motility, and vesicle trafficking $[72,73]$. The dynamic reorganization of actin is modulated by the specific activity of a number of actin binding proteins (ABPs) that either promote or inhibit actin polymerization. Actin-depolymerizing factor (ADF) is one of the most highly expressed ABPs in plants that modulate the dynamic organization of the actin cytoskeleton by promoting filamentous actin disassembly [74]. ADFs were induced by salt stress, drought, and cold in cereal plants $[43,54,75]$, which suggested that ADFs might be required for osmoregulation under osmotic stress. According to Yan [4], increased ADF levels under salt stress may result in depolymerization of actin filaments and enhanced $\mathrm{K}^{+}$influx through the inward rectification of potassium channels, which helps to restore ion homeostasis. In this study, two spots, down-regulated under $200 \mathrm{mM}$ salt stress in the roots, were identified as ADF (spots R6, R31). Another important ABP is profilin(spot R8), which was also first up and then down-regulated as the salt concentrations rose in the roots. These differences may be due to the need for growth under salt stress.

Two cell division cycle proteins (CDC48, spots 21, 22) were up-regulated under $100 \mathrm{mM} \mathrm{NaCl}$. CDC48 belongs to the ATPases associated with proteins and has many cellular activities. They are believed to function as chaperones and to regulate cell-cycle progression, membrane fusion, and the destruction misfolded secretory proteins [76, 77]. Recent studies have shown that virus movement is impaired by the overexpression of CDC48, suggesting that CDC48 controls virus movement by removal of movement proteins from the endoplasmic reticulum-transport pathway and by interfering with protein movement using microtubule dynamics [78].

\section{Signal transduction and ion transport}

Salt stress is first perceived by putative sensors in the root cell membranes and these signals are transmitted to the cellular machinery to regulate gene expression and changes in cellular metabolism designed to prevent or minimize the deleterious effects of abiotic stress. This signaling is mediated by different kinds of secondary messengers, such as $\mathrm{Ca}^{2+}$. Salinity induced increases in cytoplasmic free calcium $\left(\left[\mathrm{Ca}^{2+}\right]_{\text {cyt }}\right)$ and fluctuations in $\left[\mathrm{Ca}^{2+}\right]_{\text {cyt }}$ provide a means for relatively rapid responses and may lead to specific changes in gene expression programs [79]. Two annexin proteins (spots R15, R17) were identified in our study. Annexins are a multigene, multifunctional family of $\mathrm{Ca}^{2+}$-dependent membranebinding proteins found in both animal and plant cells, and certain annexins may be targets of $\left[\mathrm{Ca}^{2+}\right]_{\mathrm{cyt}}$ fluctuations [80]. In Arabidopsis thaliana, annexins have been shown to mediate osmotic stress and abscisic acid signal transduction [81]. In alfalfa, annexin is up-regulated in response to osmotic stress, abscisic acid (ABA), and drought [82].

A plasma membrane $\mathrm{H}^{+}$-ATPase $\left(\mathrm{PM} \mathrm{H}^{+}\right.$-ATPase, spot R3) was also up-regulated under salt stress. A response to the accumulation of $\mathrm{Na}^{+}$ions in the cytosol is their compartmentalization within the vacuole, while another response is to extrude them from the cell. In each case, the active $\mathrm{Na}^{+}$efflux requires a $\mathrm{H}^{+}$gradient across the vacuolar membrane enerated by stimulating protein expression of the vacuolar $\mathrm{H}^{+}$-ATPase [83].The accumulation of $\mathrm{PM} \mathrm{H}^{+}$-ATPase gene mRNA was induced by $\mathrm{NaCl}$ and this has been found to occur in glycophytes and halophytes. In rice, a salt-tolerant mutant highly expressed $\mathrm{PM} \mathrm{H}^{+}$-ATPase in its roots, compared to the non-mutant variety [84]. Therefore, the increased abundanceof plant plasma membrane $\mathrm{H}^{+}$-ATPase many play an important role in salt stress tolerance in alfalfa.

\section{Conclusion}

In summary, we found significant physiological and protein abundance differences during salt treatment in alfalfa. Quantitative analysis of more than 850 spots on 2D gels showed significant variations in of 36 protein spots from the roots and 27 protein spots from the shoots, which were confidently identified by MS/MS. These DAPs are mainly involved in the biological processes of photosynthesis, stress and defense, carbohydrate and energy metabolism, second metabolism, protein metabolism, transcriptional regulation, cell wall and cytoskeleton metabolism, membrane and transport, signal transduction. The diverse array of proteins affected by salt stress conditions indicates that there is a remarkable flexibility in alfalfa roots and shoots metabolism, which may contribute to its survival in salinity conditions. Further analysis demonstrated that the primary mechanisms underlying the ability of alfalfa seedlings to 
tolerate salt stress were photosynthesis, detoxifying and antioxidant, secondary metabolism, and ion transport. In parallel, physiological data, including REL, MAD and $\mathrm{H}_{2} \mathrm{O}_{2}$ contents, and the activities of antioxidant enzymes all correlated well with our proteomic results. It is worth emphasizing that some novel salt-responsive proteins were identified, such as CP12, pathogenesis-related family proteins, harvest-induced protein, isoflavone reductase, isoliquiritigenin 2'-O-methyltransferase, chalcone reductase, chalcone isomerase. qRT-PCR was used to study the gene expression levels of thefour abovementioned proteins; four patterns are consistent with those of induced protein. These novel proteins provide a good starting point for further research into their functions using genetic or other approaches. These findings significantly improve the understanding of the molecular mechanisms involved in the tolerance of plants to salt stress.

\begin{abstract}
Abbreviations
2-DE: Two-dimensional gel electrophoresis; ABP: Actin binding proteins; ADF: Actin-depolymerizing factor; ADH: Alcohol dehydrogenase; AOC: Allene oxide cyclase; APX: Ascorbic acid peroxidase; CAB: Chlorophyll a/b binding protein; CAPX: cytosolic ascorbate peroxidase; CAT: Catalase; CDC: Cell division cycle proteins; $\mathrm{CHI}$ : Chalcone isomerase; CHR: Chalcone reductase; CPGK: cytosolic phosphoglycerate kinase; ctbAPX: chloroplast thylakoidbound ascorbate peroxidase; Cyt b6/f: Cytochrome b6-f complex iron-sulfur; DAPs: Differentially abundant proteins; elF: Eukaryotic translation initiation factor; GAPDH: Glyceraldehyde-3-phosphate dehydrogenases; GO: Gene ontology; GPX: Glutathione peroxidase; GS: Glutamine synthetase; HI: Harvest-induced protein; HSP: Heat shock protein; IFR: Isoflavone reductase; IMD: 3-Isopropylmalate dehydrogenase; IOMT: Isoliquiritigenin 2'-O-methyltransferase; MD: Malate dehydrogenase; MDA: Methane Dicarboxylic Aldehyde; MIPS: L-myo-inositol 1-phosphate synthase; NABP: Nucleic acid binding proteins; NDPK1: Nucleoside diphosphate kinase 1; OEE1: Chloroplast oxygen-evolving enhancer protein 1; PDI: Protein disulfide-isomerase; POD: Peroxidase; PR: Pathogenesis-related; RBP: RNAbinding proteins; REL: Electrolyte leakage analyses; ROS: Reactive oxygen species; RP: Ribosomal proteins; SOD: Superoxide dismutase
\end{abstract}

\section{Acknowledgements}

The authors thank Dr. Tiejun Zhang and Mrs. Junmei Kang of Chinese Academy of Agricultural Science for their suggestions and critical comments.

\section{Funding}

This work was supported by the National Natural Science Foundation of China (Grant no. 31402130, 31,401,903), Modern Agro-industry Technology Research System (Grant no. CARS-35-34), and Hubei Key Laboratory of Animal Embryo Engineering and Molecular Breeding (Grant no.2012ZD201).

\section{Availability of data and materials}

Please contact author for data requests.

\section{Authors' contributions}

JX carried out sample preparation, 2DE and bioinformatics analysis. YL carried out $\mathrm{Na} / \mathrm{K}$ content, REL, MAD and $\mathrm{H}_{2} \mathrm{O}_{2}$ analysis. $\mathrm{QY}, \mathrm{HC}$, HT helped the research. YS conceived, designed, implemented and coordinated the study, and also carried out physiological experiments. All authors read and approved the final manuscript.

\section{Ethics approval and consent to participate}

Not applicable

\section{Consent for publication}

Not applicable

\section{Competing interests}

The authors declare that they have no competing interests.

\section{Publisher's Note}

Springer Nature remains neutral with regard to jurisdictional claims in published maps and institutional affiliations.

\section{Author details}

${ }^{1}$ Hubei Key Laboratory of Animal Embryo and Molecular Breeding, Institute of Animal and Veterinary Science, Hubei Academy of Agricultural Science, Yaoyuan 1, Hongshan, Wuhan, Hubei 430017, China. ${ }^{2}$ Institute of Grassland Science, China Agricultural University, 2 West Road, Yuan Ming Yuan, Beijing 100193, China. Institute of Animal Science, Chinese Academy of Agricultural Science, West Road 2, Yuan Ming Yuan, Beijing 100193, China.

Received: 8 June 2017 Accepted: 25 October 2017

Published online: 30 October 2017

\section{References}

1. Tavakkoli E, Rengasamy P, GK MD. High concentrations of $\mathrm{Na}^{+}$and $\mathrm{Cl}^{-}$ions in soil solution have simultaneous detrimental effects on growth of faba bean under salinity stress. J Exp Bot. 2010;61(15):4449-59.

2. Munns R, Tester M. Mechanisms of salinity tolerance. Annu Rev Plant Biol. 2008:59:651-81.

3. Maas E, Hoffman G. Crop salt tolerance: evaluation of existing data. In: Managing saline water for irrigation proceedings of the international salinity conference Ed HE Dregne; 1977. p. 187-98.

4. Sanden B, Sheesley B. Salinity tolerance and management for alfalfa; 2007. p. 2-4

5. Limami AM, Ricoult C, Planchet E, González EM, Ladrera R, Larrainzar E, Arrese-Igor C, Merchan F, Crespi M, Frugier F. Response of Medicago truncatula to abiotic stress. The Medicago truncatula Handbook (http://www. noble.org/MedicagoHandbook). 2006.

6. Postnikova OA, Shao J, Nemchinov LG. Analysis of the alfalfa root transcriptome in response to salinity stress. Plant Cell Physiol. 2013; 54(7):1041-55.

7. Jin H, Sun Y, Yang Q, Chao Y, Kang J, Jin H, Li Y, Margaret G. Screening of genes induced by salt stress from alfalfa. Mol Biol Rep. 2010;37(2):745-53.

8. Zhang H, Han B, Wang T, Chen S, Li H, Zhang Y, Dai S. Mechanisms of plant salt response: insights from proteomics. J Proteome Res. 2012;11(1):49-67.

9. Sobhanian H, Razavizadeh R, Nanjo Y, Ehsanpour AA, Jazii FR, Motamed N, Komatsu S. Proteome analysis of soybean leaves, hypocotyls and roots under salt stress. Proteome Sci. 2010;8(1):19.

10. Aghaei K, Ehsanpour A, Shah A, Komatsu S. Proteome analysis of soybean hypocotyl and root under salt stress. Amino Acids. 2009;36(1):91-8.

11. Xu C, Sibicky T, Huang B. Protein profile analysis of salt-responsive proteins in leaves and roots in two cultivars of creeping bentgrass differing in salinity tolerance. Plant Cell Rep. 2010;29(6):595-615.

12. Liu CW, Chang TS, Hsu YK, Wang AZ, Yen HC, Wu YP, Wang CS, Lai CC. Comparative proteomic analysis of early salt stress-responsive proteins in roots and leaves of rice. Proteomics. 2014;14(15):1759-75.

13. Patterson BD, MacRae EA, Ferguson IB. Estimation of hydrogen peroxide in plant extracts using titanium (IV). Anal Biochem. 1984;139(2):487-92.

14. Hodges DM, DeLong JM, Forney CF, Prange RK. Improving the thiobarbituric acid-reactive-substances assay for estimating lipid peroxidation in plant tissues containing anthocyanin and other interfering compounds. Planta. 1999:207(4):604-11.

15. Jiang Y, Yang B, Harris NS, Deyholos MK. Comparative proteomic analysis of $\mathrm{NaCl}$ stress-responsive proteins in Arabidopsis roots. J Exp Bot. 2007;58(13):3591-607

16. Babakhani B, Khavari-Nejad R A, Sajedi $R H$, et al. Biochemical responses of Alfalfa (Medicago sativa L.) cultivars subjected to $\mathrm{NaCl}$ salinity stress[J]. African J Biotechnol. 2011;10(55):11433-41.

17. Xiong J, Yang Q, Kang J, Sun Y, Zhang T, Margaret G, Ding W. Simultaneous isolation of DNA, RNA, and protein from Medicago Truncatula $L$. Electrophoresis. 2011:32(2):321-30.

18. Livak KJ, Schmittgen TD. Analysis of relative gene expression data using real-time quantitative PCR and the 2(-Delta Delta $C(T)$ ) method. Methods. 2001;25(4):402-8. 
19. Chaves M, Flexas J, Pinheiro C. Photosynthesis under drought and salt stress: regulation mechanisms from whole plant to cell. Ann Bot. 2009;103(4):551-60.

20. Wang ZQ, XY X, Gong QQ, Xie C, Fan W, Yang JL, Lin QS, Zheng SJ. Root proteome of rice studied by iTRAQ provides integrated insight into aluminum stress tolerance mechanisms in plants. J Proteome. 2014;98:189-205.

21. Pang Q, Chen S, Dai S, Chen Y, Wang Y, Yan X. Comparative proteomics of salt tolerance in Arabidopsis Thaliana and Thellungiella Halophila. J Proteome Res. 2010;9(5):2584-99.

22. Xu C, Huang B. Differential proteomic responses to water stress induced by PEG in two creeping bentgrass cultivars differing in stress tolerance. J Plant Physiol. 2010;167(17):1477-85.

23. Cohen I, Knopf JA, Irihimovitch V, Shapira M. A proposed mechanism for the inhibitory effects of oxidative stress on Rubisco assembly and its subunit expression. Plant Physiol. 2005:137(2):738-46.

24. Jordan DB, Chollet R, Ogren WL. Binding of phosphorylated effectors by active and inactive forms of ribulose 1, 5-bisphosphate carboxylase Biochemistry. 1983;22(14):3410-8.

25. Somerville C, Portis AR, Ogren WL. A mutant of Arabidopsis Thaliana which lacks activation of RuBP carboxylase in vivo. Plant Physiol. 1982;70(2):381-7.

26. Parker R, Flowers TJ, Moore AL, Harpham NV. An accurate and reproducible method for proteome profiling of the effects of salt stress in the rice leaf lamina. J Exp Bot. 2006;57(5):1109-18.

27. Sengupta S, Majumder AL. Insight into the salt tolerance factors of a wild halophytic rice, Porteresia coarctata: a physiological and proteomic approach. Planta. 2009;229(4):911-29.

28. Witzel K, Weidner A, Surabhi GK, Varshney RK, Kunze G, Buck-Sorlin GH, Börner A, Mock HP. Comparative analysis of the grain proteome fraction in barley genotypes with contrasting salinity tolerance during germination. Plant Cell Environ. 2010;33(2):211-22.

29. Tamoi M, Miyazaki T, Fukamizo TS. The Calvin cycle in cyanobacteria is regulated by $C P 12$ via the $N A D(H) / N A D P(H)$ ratio under light/dark conditions. Plant J. 2005:42(4):504-13.

30. Abogadallah GM. Antioxidative defense under salt stress. Plant Signal Behav. 2010;5(4):369-74

31. Stintzi A, Heitz T, Prasad V, Wiedemann-Merdinoglu S, Kauffmann S, Geoffroy P, Legrand M, Fritig B. Plant 'pathogenesis-related' proteins and their role in defense against pathogens. Biochimie. 1993:75(8):687-706.

32. Hageman R, Flesher D. The effect of an anaerobic environment on the activity of alcohol dehydrogenase and other enzymes of corn seedlings. Arch Biochem Biophys. 1960;87(2):203-9.

33. Christie PJ, Hahn M, Walbot V. Low-temperature accumulation of alcoho dehydrogenase-1 mRNA and protein activity in maize and rice seedlings. Plant Physiol. 1991;95(3):699-706.

34. Matton DP, Constabel P, Brisson N. Alcohol dehydrogenase gene expression in potato following elicitor and stress treatment. Plant Mol Biol. 1990;14(5):775-83.

35. Nam MH, Huh SM, Kim KM, Park WJ, Seo JB, Cho K, Kim DY, Kim BG, Yoon IS. Comparative proteomic analysis of early salt stress-responsive proteins in roots of SnRK2 transgenic rice. Proteome Sci. 2012;10:25.

36. Ruan SL, Ma HS, Wang SH, YP F, Xin Y, Liu WZ, Wang F, Tong JX, Wang SZ, Chen $\mathrm{HZ}$. Proteomic identification of OsCYP2, a rice cyclophilin that confers salt tolerance in rice (Oryza Sativa L.) seedlings when overexpressed. BMC Plant Biol. 2011;11:34

37. Tesfaye M, Temple SJ, Allan DL, Vance CP, Samac DA. Overexpression of malate dehydrogenase in transgenic alfalfa enhances organic acid synthesis and confers tolerance to aluminum. Plant Physiol. 2001;127(4):1836-44.

38. Dooki AD, Mayer-Posner FJ, Askari H, Aa Z, Salekdeh GH. Proteomic responses of rice young panicles to salinity. Proteomics. 2006;6(24): 6498-507.

39. C-X D, Fan H-F, Guo S-R, Tezuka T, Li J. Proteomic analysis of cucumber seedling roots subjected to salt stress. Phytochemistry. 2010;71(13):1450-9.

40. Murad AM, Molinari HB, Magalhaes BS, Franco AC, Takahashi FS, de Oliveira NG, Franco OL, Quirino BF. Physiological and proteomic analyses of Saccharum spp. grown under salt stress. PLoS One. 2014;9(6):e98463.

41. Li W, Zhang C, Lu Q, Wen X, Lu C. The combined effect of salt stress and heat shock on proteome profiling in Suaeda Salsa. J Plant Physiol. 2011; 168(15):1743-52

42. Hajheidari M, Abdollahian-Noghabi M, Askari H, Heidari M, Sadeghian SY, Ober ES, Hosseini Salekdeh G. Proteome analysis of sugar beet leaves under drought stress. Proteomics. 2005;5(4):950-60.
43. Salekdeh G, Siopongco J, Wade LJ, Ghareyazie B, Bennett J. Proteomic analysis of rice leaves during drought stress and recovery. Proteomics. 2002; 2(9):1131-45.

44. Imin N, Kerim T, Rolfe BG, Weinman JJ. Effect of early cold stress on the maturation of rice anthers. Proteomics. 2004;4(7):1873-82.

45. Xu C, Huang B. Root proteomic responses to heat stress in two Agrostis grass species contrasting in heat tolerance. J Exp Bot. 2008;59(15):4183-94.

46. Verslues PE, Batelli G, Grillo S, Agius F, Kim Y-S, Zhu J, Agarwal M, KatiyarAgarwal S, Zhu J-K. Interaction of SOS2 with nucleoside diphosphate kinase 2 and catalases reveals a point of connection between salt stress and $\mathrm{H}_{2} \mathrm{O} 2$ signaling in Arabidopsis Thaliana. Mol Cell Biol. 2007;27(22):7771-80.

47. Kidd PS, Llugany M, Poschenrieder C, Gunse B, Barcelo J. The role of root exudates in aluminium resistance and silicon-induced amelioration of aluminium toxicity in three varieties of maize (Zea Mays L.). J Exp Bot. 2001; 52(359):1339-52.

48. Winkel-Shirley B. Biosynthesis of flavonoids and effects of stress. Curr Opin Plant Biol. 2002:5(3):218-23.

49. Majee M, Maitra S, Dastidar KG, Pattnaik S, Chatterjee A, Hait NC, Das KP, Majumder AL. A novel salt-tolerant L-myo-inositol-1-phosphate synthase from Porteresia coarctata (Roxb.) Tateoka, a halophytic wild rice molecular cloning, bacterial overexpression, characterization, and functional introgression into tobacco-conferring salt tolerance phenotype. J Biol Chem. 2004;279(27):28539-52

50. Ishitani M, Majumder AL, Bornhouser A, Michalowski CB, Jensen RG, Bohnert $\mathrm{HJ}$. Coordinate transcriptional induction of myo-inositol metabolism during environmental stress. Plant J. 1996:9(4):537-48.

51. Fougère $F$, Le Rudulier $D$, Streeter JG. Effects of salt stress on amino acid, organic acid, and carbohydrate composition of roots, bacteroids, and cytosol of alfalfa (Medicago Sativa L.). Plant Physiol. 1991;96(4):1228-36.

52. Skopelitis DS, Paranychianakis NV, Paschalidis KA, Pliakonis ED, Delis ID, Yakoumakis DI, Kouvarakis A, Papadakis AK, Stephanou EG, RoubelakisAngelakis KA. Abiotic stress generates ROS that signal expression of anionic glutamate dehydrogenases to form glutamate for proline synthesis in tobacco and grapevine. Plant Cell. 2006;18(10):2767-81.

53. Wang Z-Q, Yuan Y-Z, Ou J-Q, Lin Q-H, Zhang C-F. Glutamine synthetase and glutamate dehydrogenase contribute differentially to proline accumulation in leaves of wheat $(<\mathrm{i}>$ Triticum aestivum $</ \mathrm{i}>$ ) seedlings exposed to different salinity. J Plant Physiol. 2007;164(6):695-701.

54. Yan S, Tang Z, Su W, Sun W. Proteomic analysis of salt stress-responsive proteins in rice root. Proteomics. 2005;5(1):235-44.

55. Nam MH, Huh SM, Kim KM, Park WJ, Seo JB, Cho K, Kim DY, Kim BG, Yoon IS. Comparative proteomic analysis of early salt stress-responsive proteins in roots of SnRK2 transgenic rice. Proteome Sci. 2012;10(25):2-19.

56. Ziegler J, Stenzel I, Hause B, Maucher H, Hamberg M, Grimm R, Ganal M, Wasternack C. Molecular cloning of Allene oxide Cyclase. The enzyme establishing the stereochemistry of octadecanoids and jasmonates. J Biol Chem. 2000:275(25):19132-8.

57. Devoto A, Turner JG. Jasmonate-regulated Arabidopsis stress signalling network. Physiol Plant. 2005;123(2):161-72.

58. Yamada A, Saitoh T, Mimura T, Ozeki Y. Expression of mangrove allene oxide cyclase enhances salt tolerance in Escherichia coli, yeast, and tobacco cells. Plant Cell Physiol. 2002;43(8):903-10.

59. Sutka M, Li G, Boudet J, Boursiac Y, Doumas P, Maurel C. Natural variation of root hydraulics in Arabidopsis grown in normal and salt-stressed conditions. Plant Physiol. 2011:155(3):1264

60. Wu L, Zhao FA, Fang W, Xie D, Hou J, Yang X, Zhao Y, Tang Z, Nie L, Lv S. Identification of early salt stress responsive proteins in seedling roots of upland cotton (Gossypium Hirsutum L.) employing iTRAQ-based proteomic technique. Front Plant Sci. 2015;6:732

61. Gruber CW, Čemažar M, Heras B, Martin UL, Craik DJ. Protein disulfide isomerase: the structure of oxidative folding. Trends Biochem Sci. 2006;31(8):455-64.

62. Nohzadeh MS, Habibi RM, Heidari M, Salekdeh GH. Proteomics reveals new salt responsive proteins associated with rice plasma membrane. Biosci Biotechnol Biochem. 2014:71(9):2144-54.

63. Song A, Zhu X, Chen F, Gao H, Jiang J, Chen S. A chrysanthemum heat shock protein confers tolerance to abiotic stress. Int J Mol Sci. 2014;15(3):5063-78

64. Lv D-W, Subburaj S, Cao M, Yan X, Li X, Appels R, Sun D-F, Ma W, Yan Y-M. Proteome and phosphoproteome characterization reveals new response and defense mechanisms of Brachypodium Distachyon leaves under salt stress. Mol Cell Proteomics. 2014;13(2):632-52. 
65. Babbitt SE, Kiss A, Deffenbaugh AE, Chang Y-H, Bailly E, Erdjument-Bromage $H$, Tempst P, Buranda T, Sklar LA, Baumler J. ATP hydrolysis-dependent disassembly of the 265 proteasome is part of the catalytic cycle. Cell. 2005; 121(4):553-65

66. Darnell J, Lodish H, Baltimore D. Molecular cell biology[]]. Yale J Biol Med. 2008;60(3):292-385.

67. Ahlert D, Piepenburg K, Kudla J, Bock R. Evolutionary origin of a plant mitochondrial group II intron from a reverse transcriptase/maturaseencoding ancestor. J Plant Res. 2006;119(4):363-71.

68. Matsuura M, Noah JW, Lambowitz AM. Mechanism of maturase-promoted group II intron splicing. EMBO J. 2001;20(24):7259-70.

69. Yang C, Wang L, Siva VS, Shi X, Jiang Q, Wang J, Zhang H, Song L. A novel cold-regulated cold shock domain containing protein from scallop Chlamys Farreri with nucleic acid-binding activity. PLoS One. 2012;7(2):e32012.

70. Wolffe AP. Structural and functional properties of the evolutionarily ancient Y-box family of nucleic acid binding proteins. BioEssays. 1994;16(4):245-51.

71. Graumann PL, Marahiel MA. A superfamily of proteins that contain the coldshock domain. Trends Biochem Sci. 1998;23(8):286-90.

72. Hussey PJ, Ketelaar T, Deeks MJ. Control of the actin cytoskeleton in plant cell growth. Annu Rev Plant Biol. 2006;57:109-25.

73. Kandasamy MK, Burgos-Rivera B, McKinney EC, Ruzicka DR, Meagher RB. Class-specific interaction of profilin and ADF isovariants with actin in the regulation of plant development. Plant Cell. 2007;19(10):3111-26.

74. Pope BJ, Gonsior SM, Yeoh S, McGough A, Weeds AG. Uncoupling actin filament fragmentation by cofilin from increased subunit turnover. J Mol Biol. 2000;298(4):649-61.

75. Ouellet F, Carpentier É, Cope MJT, Monroy AF, Sarhan F. Regulation of a wheat actin-depolymerizing factor during cold acclimation. Plant Physiol. 2001;125(1):360-8

76. Buchberger A. Control of ubiquitin conjugation by $\mathrm{cdc} 48$ and its cofactors. In: Conjugation and Deconjugation of Ubiquitin family modifiers. Springer. 2010;54(54):17-30.

77. Vembar SS, Brodsky JL. One step at a time: endoplasmic reticulumassociated degradation. Nat Rev Mol Cell Biol. 2008;9(12):944-57.

78. Niehl A, Amari K, Gereige D, Brandner K, Mély Y, Heinlein M. Control of tobacco mosaic virus movement protein fate by CELL-DIVISION-CYCLE protein48. Plant Physiol. 2012;160(4):2093-108.

79. Knight $\mathrm{H}$, Trewavas AJ, Knight MR. Calcium signalling in Arabidopsis Thaliana responding to drought and salinity. Plant J. 1997;12(5):1067-78.

80. Mortimer JC, Laohavisit A, Macpherson N, Webb A, Brownlee C, Battey NH, Davies JM. Annexins: multifunctional components of growth and adaptation. J Exp Bot. 2008;59(3):533-44.

81. Lee S, Lee EJ, Yang EJ, Lee JE, Park AR, Song WH, Park OK. Proteomic identification of annexins, calcium-dependent membrane binding proteins that mediate osmotic stress and abscisic acid signal transduction in Arabidopsis. Plant Cell. 2004;16(6):1378-91.

82. Kovács I, Ayaydin F, Oberschall A, Ipacs I, Bottka S, Pongor S, Dudits D, Tóth ÉC. Immunolocalization of a novel annexin-like protein encoded by a stress and abscisic acid responsive gene in alfalfa. Plant J. 1998;15(2):185-97.

83. Zhang JL, Shi H. Physiological and molecular mechanisms of plant salt tolerance. Photosynth Res. 2013;115(1):1.

84. Zhang J-S, Xie C, Li Z-Y, Chen S-Y. Expression of the plasma membrane H+-ATPase gene in response to salt stress in a rice salt-tolerant mutant and its original variety. Theor Appl Genet. 1999;99(6):1006-11.

\section{Submit your next manuscript to BioMed Central and we will help you at every step:}

- We accept pre-submission inquiries

- Our selector tool helps you to find the most relevant journal

- We provide round the clock customer support

- Convenient online submission

- Thorough peer review

- Inclusion in PubMed and all major indexing services

- Maximum visibility for your research

Submit your manuscript at www.biomedcentral.com/submit

Biomed Central 